\title{
Interlocked Porphyrin Switches
}

\section{Ruud G. E. Coumans, Johannes A. A. W. Elemans, * Alan E. Rowan,* and Roeland J. M. Nolte*}

\begin{abstract}
We describe the synthesis of a series of catenanes and molecular necklaces from porphyrin-glycoluril cage compounds and bis-olefin terminated viologens by an olefin metathesis protocol. The length of the chain connecting the olefin substituents with the viologen has a marked effect on the products of the ring closure
\end{abstract}

reaction. Long chains yield [2]- and [3]-catenane structures, whereas short chains give a mixture of [3]-catenane and [4]- and [5]-molecular necklaces. For comparison also several [2]rotaxane compounds were prepared. The interlocked catenane and rotaxane structures display switching behavior, which can be controlled by the addition of acid and base. The kinetic and thermodynamic parameters of the switching processes have been determined by NMR.

\section{Keywords: Interlocked structures, porphyrins, switches, rotaxanes,} catenanes

\section{Introduction}

The development and study of mechanically interlocked molecules such as rotaxanes, catenanes, molecular necklaces and Borromean rings remains a fascinating area of supramolecular chemistry. ${ }^{[1]}$ These interlocked architectures have shown to be potential candidates for incorporation in molecular memory devices due to their tunable switching (on/off) behaviour. The group of Stoddart, for example, has demonstrated that it is possible to immobilize switchable [2]catenanes onto a surface, while retaining their switching behaviour, resulting in prototypical molecular memories. ${ }^{[2]}$ The same group has more recently shown that certain [3]rotaxanes, when grafted onto a thin metal surface, are capable of bending the surface as a result of electrochemically induced contraction of the rotaxanes. ${ }^{[3]}$ These examples clearly demonstrate that interlocked molecules are promising building blocks, which can be applied as functional elements in nanotechnology. ${ }^{[4]}$ They have stimulated us to investigate interlocked structures that contain one or more functional components, viz. porphyrins, as part of a project aimed at developing a so-called molecular Turing machine. In 1937 Alan Turing described a theoretical machine that can manipulate symbols on a strip of tape according to a table of rules obtained from a tape head (see Figure 1a) ${ }^{[5]}$ A Turing machine is a simple device, but nevertheless can be adapted to simulate the logic of any computer algorithm. We have embarked on a program to construct a molecular Turing machine, i.e. a molecular device that can perform

[a] Dr. R. G. E. Coumans, Dr. J. A. A. W. Elemans, Prof. A. E. Rowan, Prof. R. J. M. Nolte

Radboud University Nijmegen

Institute for Molecules and Materials

Heyendaalseweg 135, 6525 AJ Nijmegen (The Netherlands)

Fax: (+31) 243652929

E-mail: R.Nolte@ science.ru.nl, A.Rowan@science.ru.nl,

J.Elemans@science.ru.nl actions on a polymer tape according to instructions from a tape head. The blueprint is shown in Figure 1c. As a tape, polymers will be used containing sites that can be chemically transformed, e.g. alkene double bonds in polybutadiene that can be converted into epoxide functions. $^{[6]}$ The tape head will be a glycoluril double cage compound of the type shown in Figure 1b. It contains two metal porphyrin cages that are held together by a ligand bond $(1,4-$ diazabicyclo[2.2.2]octane) and by hydrogen bonding interactions. In a previous paper we have shown that in this compound information can be transferred from one porphyrin cage to the other by four positive allosteric interactions. ${ }^{[7]}$ One of the cages will contain a ring compound, i.e. a catenane, that can rotate and provide the instructions. The other cage will be threaded onto a polymer chain (see Figure 1). ${ }^{[8]}$ a)

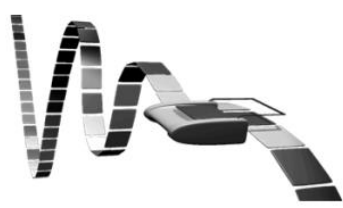

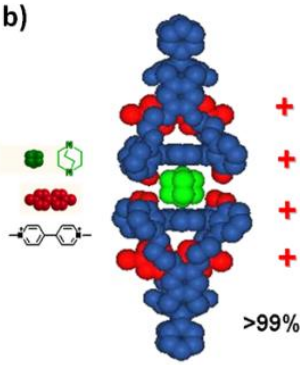

c)

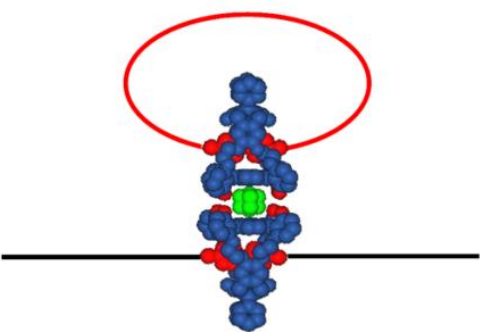

Figure 1. a) Artist impression of a Turing machine. b) Double glycoluril cage compound, in which information can be transferred by four positive (+ sign) allosteric interactions. c) Blueprint of a molecular Turing machine. 
The components in the ring have to be designed in such a way that information can be transferred to the polymer tape, e.g. by allosteric actions. One such component may be a pyridine group, which when positioned in the tape head will give the instruction to perform a catalytic reaction on an alkene double bond in the polymer tape. Another component could be a viologen group or a (protonated) amine function or a light switchable azobenzene group, which may give the instruction to the tape head to bind to a certain place on the polymeric tape. The ultimate goal would be to modify a polymer substrate with a repeating pattern, which is imparted by the catenane.

As a first step in the construction of such a molecular Turing machine we decided to study the synthesis of a porphyrin-glycoluril rotaxane architecture using olefin metathesis chemistry. We have already demonstrated that olefin metathesis in combination with the selective recognition of viologens by porphyrin-glycoluril host 1 (Scheme 1) is an excellent way to synthesize rotaxanes. ${ }^{[9]}$ This stimulated us to further explore this approach and use it for the synthesis of porphyrin-based catenanes, that might function as simple molecular switches. Here, the synthesis and (photo)physical properties of a variety of interlocked structures (catenanes, molecular necklaces and rotaxanes) based on porphyrin host $\mathbf{1}$ are described.

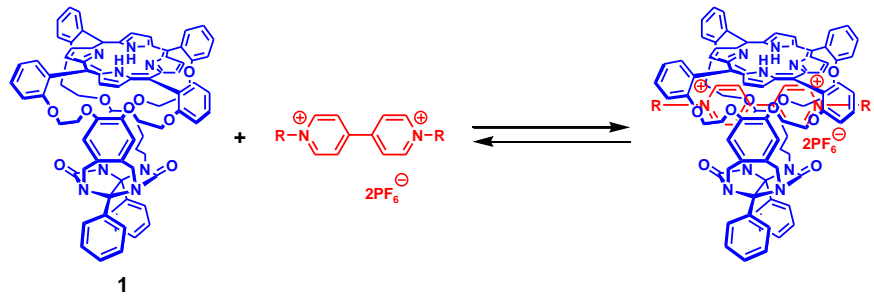

Scheme 1. Formation of a host-guest complex between the cavity-containing porphyrin $\mathbf{1}$ and a viologen guest.

\section{Results and Discussion}

Design. Our strategy to construct porphyrin-containing catenanes is based on an olefin metathesis protocol, which was published previously by our group. ${ }^{[9]}$ In organic solvents porphyrin host $\mathbf{1}$ forms very stable complexes with viologen ( $N, N^{\prime}$-dialkyl-4,4bipyridinium) derivatives (Scheme 1). ${ }^{[10]}$ The strong binding of these guests relies on a combination of factors, viz. $\pi-\pi$ stacking interactions between the aromatic surfaces of the viologen and of $\mathbf{1}$, electrostatic interactions between the positive charges on the guest and the crown ether moieties of $\mathbf{1}$, and $\mathrm{C}-\mathrm{H} \cdots \mathrm{O}$ hydrogen bonding between the $\alpha$-bipyridinium protons and the crown ether and carbonyl oxygen atoms of $\mathbf{1}$. When viologens that contain terminal olefins as $N$-substituents are complexed in the cavity of $\mathbf{1}$, the resulting host-guest complexes can in principle be subjected to olefin metatheses reactions, so that interlocked porphyrin-containing species are generated. Similar olefin ring-closing and cross metathesis protocols have proven to be very effective for the high yield synthesis of a variety of interlocked molecules. ${ }^{[11]}$ In the research described in this paper we will make use of two olefincontaining viologens, 3 and $\mathbf{4}$ (see Scheme 2), that differ in the length of the bipyridine $N$-substituents.

Synthesis of olefin-containing viologens. The synthesis of viologen 3 started with the etherification of 1,10-dibromodecane with 9-decenol using $\mathrm{NaH}$ as a base in DMF, affording bromide derivative $\mathbf{2}$ in $44 \%$ yield after purification by column chromatography (Scheme 2). This compound was subsequently coupled to 4,4'-bipyridine in hot DMF, after which ion exchange with $\mathrm{NH}_{4} \mathrm{PF}_{6}$ in water gave 3 in $23 \%$ yield, after recrystallization from methanol. To obtain a viologen with a shorter substituent, 4,4 'bipyridine was reacted with an excess of 8-bromooctene in hot DMF, followed by ion-exchange with $\mathrm{NH}_{4} \mathrm{PF}_{6}$, to give viologen 4 in $61 \%$ yield.

Synthesis of catenanes and molecular necklaces. The mixing of porphyrin clip $\mathbf{1}$ with viologen 3 in $\mathrm{CHCl}_{3} /$ acetone $(1: 1, \mathrm{v} / \mathrm{v})$, followed by precipitation of the product in $n$-hexane, quantitatively furnished [2]pseudorotaxane $\mathbf{5}$ (Scheme 3). Indicative for [2]pseudorotaxane formation are the large complexation-induced shifts observed in the ${ }^{1} \mathrm{H}$ NMR spectrum $\left(\mathrm{CDCl}_{3}\right)$ for the signals of the aromatic viologen protons $\mathrm{H}_{\mathrm{a}}(\Delta \delta=-2.65 \mathrm{ppm})$ and $\mathrm{H}_{\mathrm{b}}(\Delta \delta=-$ $4.07 \mathrm{ppm}$ ), as a result of shielding by the porphyrin macrocycle and the aromatic side walls of $\mathbf{1}$. The complex was readily soluble in $\mathrm{CH}_{2} \mathrm{Cl}_{2}$, which set the stage for a ring-closing metathesis reaction (RCM) of the terminal alkene groups of the viologen using the first generation Grubbs' catalyst $\mathrm{RuCHPh}(\mathrm{Cl})_{2}\left(\mathrm{PCy}_{3}\right)_{2}$ (Scheme 3).

To minimize intermolecular crosslinking, the reaction was performed under high dilution conditions $([\mathbf{5}]=\mathrm{ca} .0 .0005 \mathrm{M})$. At these concentrations, more than $99 \%$ of $\mathbf{1}$ is complexed by $\mathbf{3}$ because of the high association constant $\left(K_{\mathrm{a}}\right.$ $\approx 10^{7} \mathrm{M}^{-1}$ ). Subjecting a solution of $\mathbf{5}$ in $\mathrm{CH}_{2} \mathrm{Cl}_{2}$ to $20 \mathrm{~mol} \%$ of Grubbs' catalyst for 24 hours at room temperature resulted in a mixture of products, of which [2]catenane 6 could be isolated in $69 \%$ yield after column chromatography, as a mixture of $E / Z$ isomers in a 4:1 ratio. [3]Catenane 7 was also isolated in $3 \%$ yield, as a mixture of $E / E, E / Z$, and $Z / Z$ isomers (total $E / Z$ ratio $=4: 1$ ). Both catenanes contain a very large macrocycle: a 48 membered ring in the case of 6 and a 96 -membered one in the case of $7 .^{[12]}$ The MALDI-TOF spectra of the [2]catenanes (Figure 2a-b) showed one peak for $\mathbf{6}$ at $m / z=2064 \mathrm{amu}$, corresponding to $\left[\mathrm{M}-2 \mathrm{PF}_{6}\right]^{+}$and four peaks for $\mathbf{7}$ at $m / z=4128,4273,4415,4560 \mathrm{amu}$, corresponding to $\left[\mathrm{M}-\mathrm{nPF}_{6}\right]^{+}(\mathrm{n}=1-4)$.

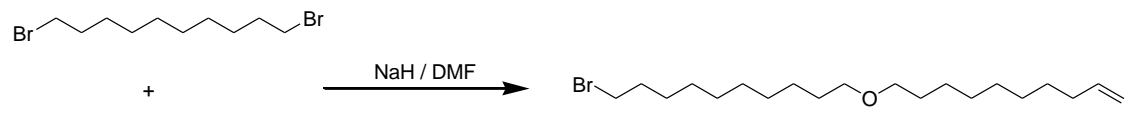

2

HO

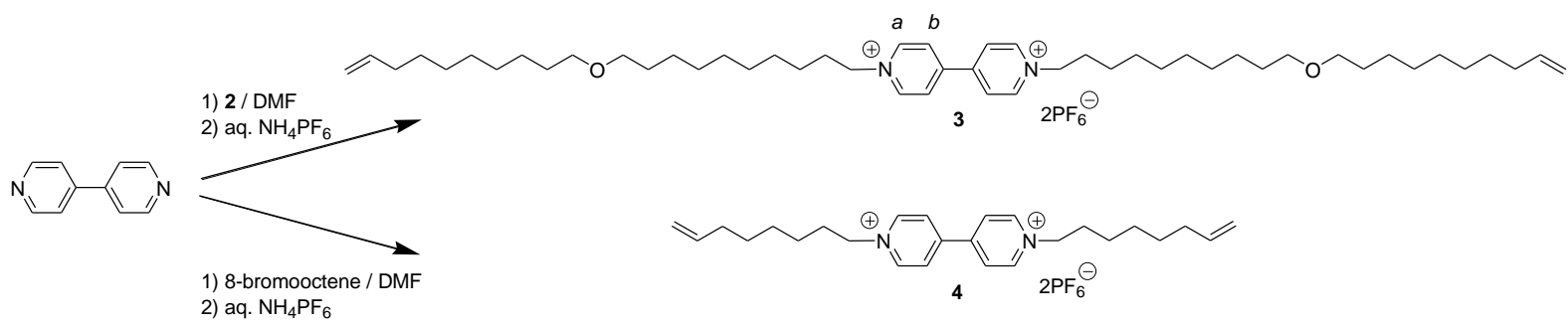

Scheme 2. Synthesis of olefin-terminated viologens 


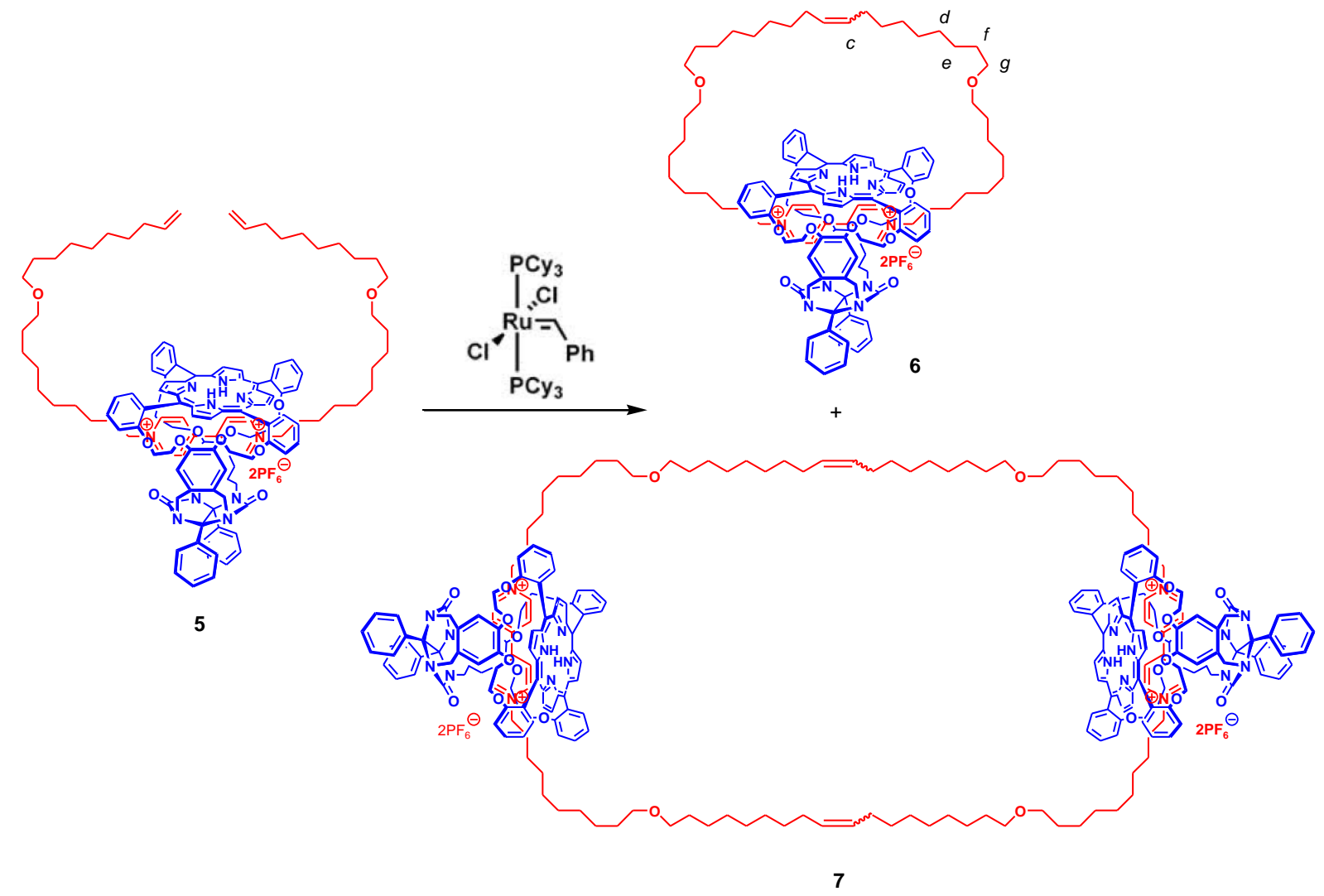

Scheme 3. Synthesis of [2]pseudorotaxane 5, [2]catenane 6 and [3]catenane 7.

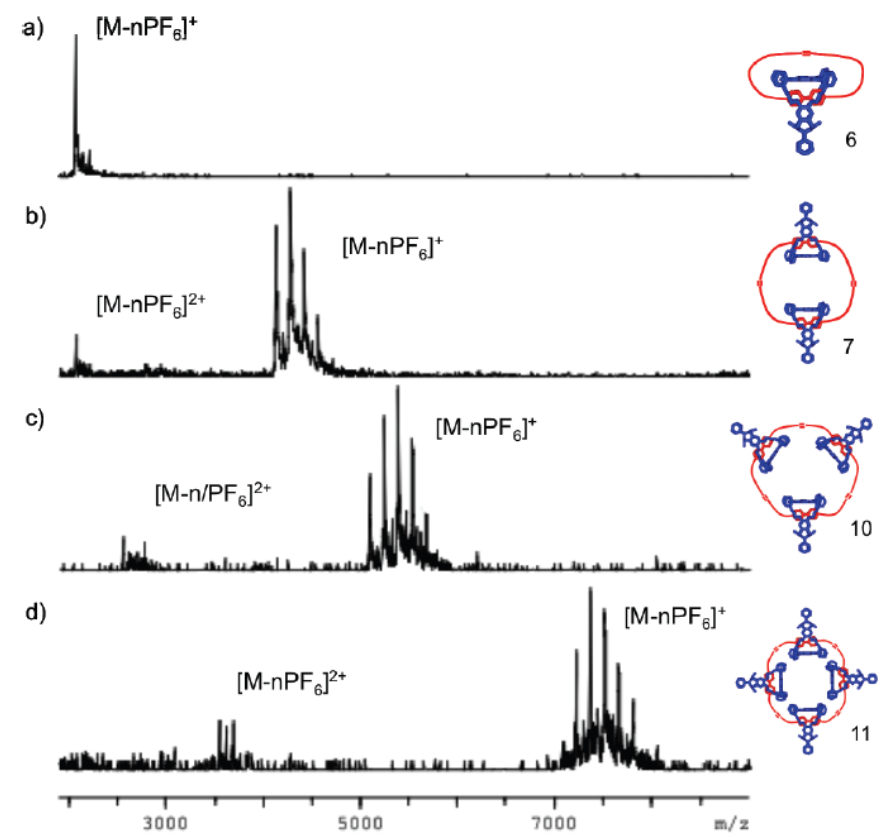

Figure 2. MALDI-TOF spectra of (a) [2]catenane 6, (b) [3]catenane 7, (c) [4]molecular necklace $\mathbf{1 0}$ and (d) [5]molecular necklace $\mathbf{1 1}$

The 2D-NOESY spectrum of $\mathbf{6}$ revealed nOe-contacts between the pyrrole $\mathrm{NH}$ protons of the porphyrin and the aromatic protons $\mathrm{H}_{\mathrm{a}}$ and $\mathrm{H}_{\mathrm{b}}$ (see Scheme 2) of the viologen, which indicates that the latter moiety is situated inside the cavity of $\mathbf{1}$. The resonances of the trans-alkene protons $\mathrm{H}_{\mathrm{c}}$ (see Scheme 3 ) are shifted upfield to $\delta=$ $4.87 \mathrm{ppm},(\Delta \delta \approx-0.5 \mathrm{ppm}$ compared to other internal alkenes), which is attributed to shielding effects by the porphyrin macrocycle and/or the aromatic side walls of $\mathbf{1}$. In the ${ }^{1} \mathrm{H}$ NMR spectrum of [3]catenane 7, the trans-alkene protons resonate at $\delta=5.39 \mathrm{ppm}$,

indicating that the alkene parts of the thread are in this case situated further away from the aromatic surfaces of the host.

To investigate the effect of spacer length on the outcome of the metathesis reaction, the same RCM reaction was repeated using viologen 4, which has shorter $N$-substituents. The desired [2]pseudorotaxane $\mathbf{8}$ was readily assembled according to the aforementioned procedure. Exposing a $0.001 \mathrm{M}$ solution of $\mathbf{8}$ in $\mathrm{CH}_{2} \mathrm{Cl}_{2}$ to $20 \mathrm{~mol} \%$ of Grubbs' catalyst in refluxing $\mathrm{CH}_{2} \mathrm{Cl}_{2}$ for 24 hours gave a mixture of products, containing [3]catenane $\mathbf{9}$, 
[4]molecular necklace 10, [5]molecular necklace $\mathbf{1 1}$ and some higher cyclooligomers (Scheme 4). ${ }^{[13]}$ It appeared that refluxing the solution resulted in a much better conversion than performing the reaction at room temperature. The necklaces $\mathbf{1 0}$ and $\mathbf{1 1}$ could be isolated from the product mixture in $18 \%$ and $11 \%$ yield, respectively ( $\sim 95 \%$ pure), using a combination of silica and size exclusion chromatography. To the best of our knowledge, these are the first examples of porphyrin-containing molecular necklaces. ${ }^{[14]}$ MALDI-TOF showed five peaks for necklace 10 at $\mathrm{m} / \mathrm{z}=5088$, $5234,5378,5523$ and $5668 \mathrm{amu}$, corresponding to $\left[\mathrm{M}-\mathrm{nPF}_{6}\right]^{+}(\mathrm{n}=2-$ 6) (Figure 2c). For necklace 11, MALDI-TOF showed six peaks at $m / z=7073,7218,7363,7508,7654$ and $7798 \mathrm{amu}$, corresponding to $\left[\mathrm{M}-\mathrm{nPF}_{6}\right]^{+}(\mathrm{n}=1-6)$ (Figure 2d). No formation of a [2]catenane was observed, even when the reaction was performed at higher dilution $(0.0005 \mathrm{M})$, which indicates that the $\mathrm{N}$-substituents of $\mathbf{4}$ are too short to be engaged in an intramolecular crosslink. Hence, by varying the spacer length it is possible to control, at least to some extent, the outcome of the metathesis reaction.

Synthesis of [2]rotaxanes. It was decided to also synthesize a series of [2] rotaxanes based on 1, containing threads of different lengths (Scheme 5), in order to be able to compare their physical properties with those of the aforementioned catenane structures.

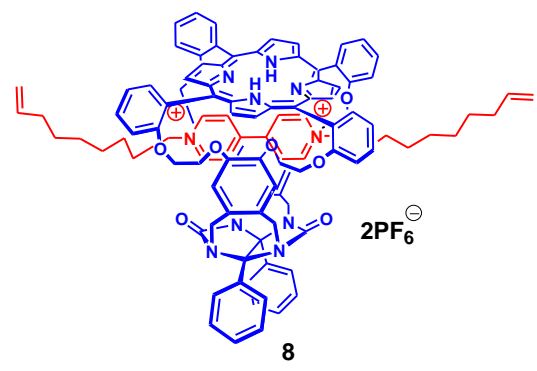

Scheme 4. Synthesis of [3]catenane $\mathbf{9}$ and molecular necklaces $\mathbf{1 0}$ and $\mathbf{1 1 .}$

Scheme 5. Synthesis of [2] rotaxanes 18-20.

The synthesis of [2] rotaxanes 18-20 was based on our previously reported protocol. ${ }^{[9]}$ It started with the synthesis of bulky alkyl bromides 12-14 by reacting the appropriate dibromides (in the case of 12 and 13) with 3,5-di-tert-butylphenol under basic conditions in

DMF. Compounds $\mathbf{1 2}$ and $\mathbf{1 3}$ were isolated in $70-80 \%$ yield).

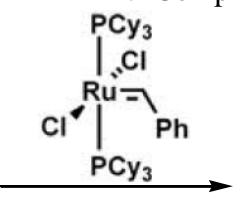

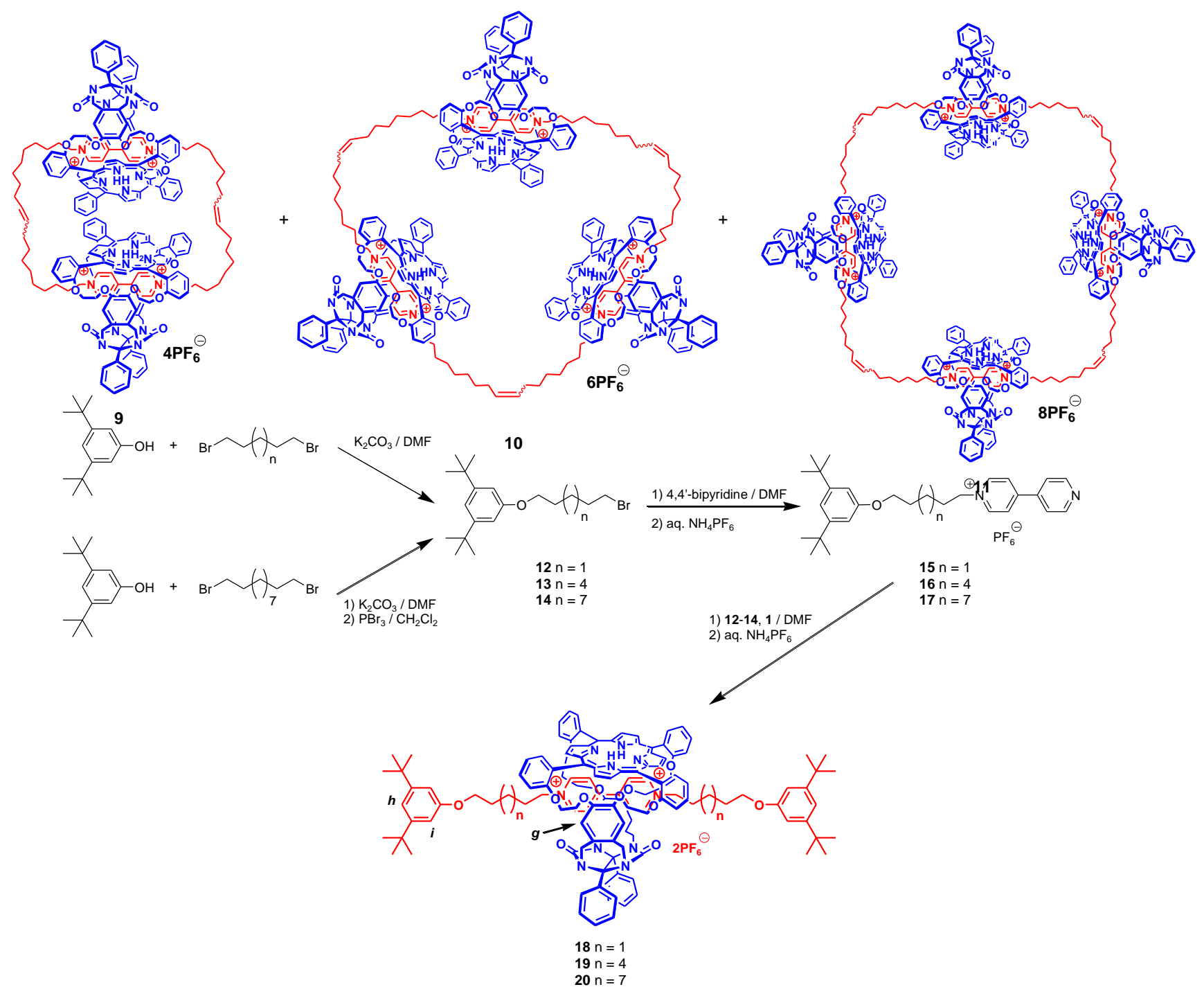


Bromide 14 was synthesized by first coupling 11-bromoundecan-1ol and 3,5-di-tert-butylphenol (yield: 77\%), after which the alcohol was converted to a bromide by reacting it with $\mathrm{PBr}_{3}$ in $\mathrm{CH}_{2} \mathrm{Cl}_{2}$ to give 14 in $62 \%$ yield. This procedure was followed since it appeared impossible to purify the product mixture obtained after reaction of the bulky phenol with 1,11-dibromoundecane. The bulky bromides were reacted with an excess of 4,4'-bipyridine in $\mathrm{MeCN}$ to give mono-alkylated bipyridium derivatives $\mathbf{1 5 - 1 7}$ in yields up to $90 \%$, after ion-exchange with aqueous $\mathrm{NH}_{4} \mathrm{PF}_{6}$. It was now possible to synthesize the corresponding rotaxanes 18 -20 by simply heating a mixture of 1, five equivalents of respectively 15-17 and 40 equivalents of respectively 12-14 in DMF. After ion exchange with aqueous $\mathrm{NH}_{4} \mathrm{PF}_{6}$ and purification by column chromatography, the [2] rotaxanes were isolated in yields up to $60 \%$.

Protonation-induced shuttling. With the novel interlocked porphyrins at hand, it was decided to investigate if these molecules could be used as molecular switches. We anticipated that protonation of the pyrrole nitrogen atoms of the porphyrin ring with trifluoroacetic acid (TFA) would result in an expulsion of the viologen moiety from the porphyrin cavity due to Coulombic repulsion, as was observed previously in a related system published by Gunter et al. ${ }^{[15]}$ Indeed, the addition of $5 \mathrm{vol} \%$ of TFA to a $\mathrm{CDCl}_{3}$ solution of the simplest [2]catenane, $\mathbf{6}$, providing protonated [2]catenane $[6 \cdot 2 \mathrm{H}]^{2+}$, resulted in dramatic downfield shifts for viologen resonances $H_{a}(\Delta \delta=+2.78 \mathrm{ppm}$, see Scheme 2 for proton numbering) and $\mathrm{H}_{\mathrm{b}}(\Delta \delta=+3.77 \mathrm{ppm})$, because of expulsion of the viologen from the cavity of $\mathbf{1}$ (Figure 3 ). In addition, a significant downfield shift was observed for the alkene resonance $H_{c}(\Delta \delta=$ $+0.53 \mathrm{ppm}$ ). Both observations indicate a rotation of the viologencontaining ring with respect to the porphyrin host.

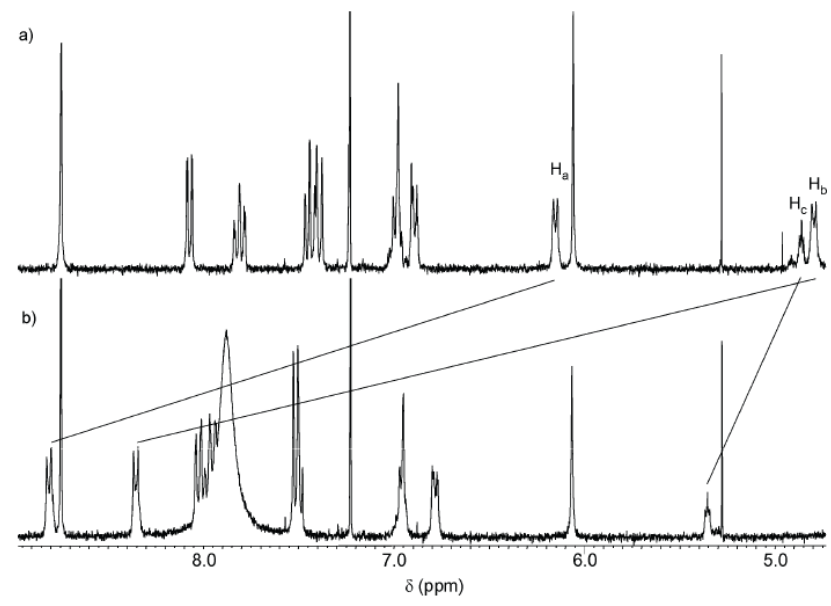

Figure 3 Part of the $1 \mathrm{H}$ NMR spectra (300 MHz) of (a) unprotonated [2]catenane 6 and (b) protonated $[2]$ catenane $[6 \cdot 2 \mathrm{H}]^{2+}$. See Schemes 2 and 3 for proton numbering.

Since the resonances of $\mathrm{H}_{\mathrm{a}}, \mathrm{H}_{\mathrm{b}}$ and $\mathrm{H}_{\mathrm{c}}$ appear at positions where they are expected in uncatenated compounds, it can be concluded that the porphyrin bead in $[6 \cdot 2 \mathrm{H}]^{2+}$ does not reside on the viologen, whereas in 6 it exclusively resides on this moiety. Detailed investigations using COSY and 2D-NOESY spectroscopy revealed that the protonated porphyrin in $[6 \cdot 2 \mathrm{H}]^{2+}$ is situated near one of the ether oxygen atoms of the thread, possibly because of the presence of $\mathrm{NH}^{+}-\mathrm{O}$ hydrogen bonds, since increasingly larger upfield shifts are observed for the signals of $\mathrm{H}_{\mathrm{d}}, \mathrm{H}_{\mathrm{e}}$ and $\mathrm{H}_{\mathrm{f}}$ (Table 1). The resonance for proton $\mathrm{H}_{\mathrm{g}}$ in $[6 \cdot 2 \mathrm{H}]^{2+}$ could not be identified, as it was either obscured by other signals, or severely broadened.

The symmetry observed in the NMR spectrum of $[6 \cdot 2 \mathrm{H}]^{2+}$ can be attributed to the porphyrin bead shuttling between two degenerate states in which the porphyrin is near the oxygen atoms in the viologen-containing ring. ${ }^{[16]}$ To investigate this dynamic behaviour further, variable temperature ${ }^{1} \mathrm{H}$ NMR (VT-NMR) spectroscopy was carried out on $[6 \cdot 2 \mathrm{H}]^{2+}$. As is shown in Figure 4, going down in temperature causes dramatic changes in the NMR spectrum.

Table $1{ }^{1} \mathrm{H}$ NMR data of [2]catenane 6 and protonated catenane $[6 \cdot 2 \mathrm{H}]^{2+} .{ }^{[a]}$

\begin{tabular}{|c|c|c|c|}
\hline Proton & $\begin{array}{c}\mathbf{6} \\
(\delta, \mathrm{ppm}) \\
\end{array}$ & $\begin{array}{l}{[\mathbf{6} \cdot 2 \mathrm{H}]^{2+}} \\
(\delta, \mathrm{ppm})\end{array}$ & $\begin{array}{c}\text { Shift } \\
(\delta, \mathrm{ppm})\end{array}$ \\
\hline a & 6.18 & 8.96 & +2.78 \\
\hline $\mathrm{b}$ & 4.80 & 8.57 & +3.77 \\
\hline c & 4.87 & 5.40 & +0.53 \\
\hline d & 1.20 & 0.63 & -0.57 \\
\hline $\mathrm{e}$ & 1.50 & 0.20 & -1.30 \\
\hline $\mathrm{f}$ & 1.68 & -0.60 & -2.28 \\
\hline
\end{tabular}

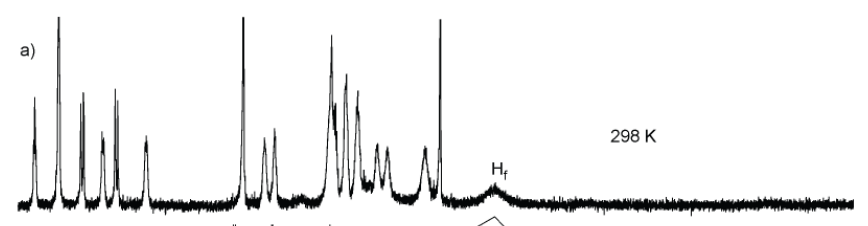

b)

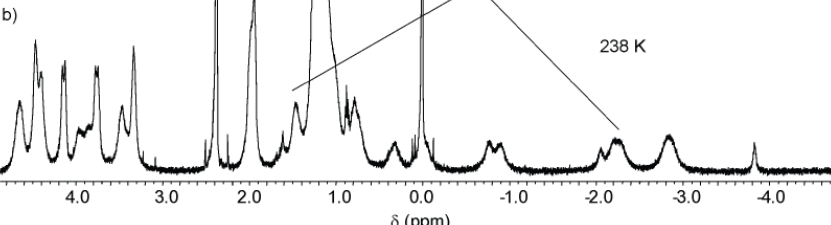

Figure 4. Parts of the ${ }^{1} \mathrm{H}$ NMR spectra $(500 \mathrm{MHz})$ of $[6 \cdot 2 \mathrm{H}]^{2+}$ at (a) $298 \mathrm{~K}$ and (b) 238 K. See Scheme 3 for proton numbering.

Notably, new resonances appear at high field ( 0 to $-4 \mathrm{ppm})$, most probably as a result of shielding effects exerted by the porphyrin ring current on protons present inside the cavity. Low temperature COSY experiments were used to assign some of these resonances, as is indicated for proton $\mathrm{H}_{\mathrm{f}}$. Not all signals could be assigned due to the broadening of the spectra. However, it is clear from these experiments that protonation induces a motion in the [2]catenane, involving a switching of the porphyrin moiety between two degenerate states (Scheme 6).

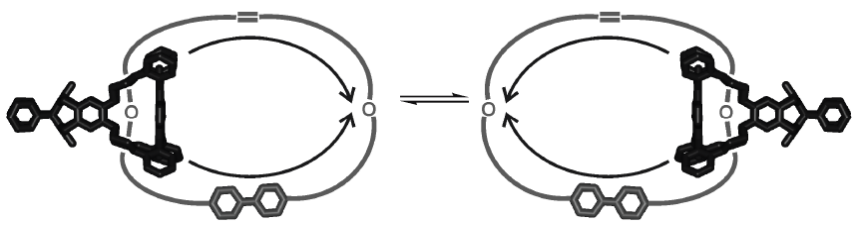

Scheme 6. Schematic representation of the proposed dynamic behaviour in [2]catenane $[6 \cdot 2 \mathrm{H}]^{2+}$, demonstrating the possible pathways of movement of porphyrin host $\mathbf{1}$ along the thread between two degenerate states.

Using the coalescence method, ${ }^{[17]}$ the rate and the corresponding activation Gibbs energy for this dynamic process were estimated to be $k_{278}=7.0 \times 10^{3} \mathrm{~s}^{-1}$ and $\Delta G^{\ddagger} 278=47 \mathrm{~kJ} \mathrm{~mol}^{-1}$, respectively. It is however not known if in this dynamic behaviour the shuttling between the two degenerate states takes place via the double bond, via the viologen moiety or via both routes (Scheme 6).

In order to obtain a better picture of the dynamic process, it was decided to investigate in more detail how a viologen can create a barrier for a shuttling process of the type shown above. To this end, the dynamic behaviour of the series of [2] rotaxanes 18-20 as result of their protonation with TFA was investigated. In this type of interlocked molecule, similar dynamic behavior as observed for the [2]catenane is only possible when the porphyrin overcomes the 
electrostatic barrier posed by the viologen. Protonating [2]rotaxane 18, to give $[\mathbf{1 8} \cdot 2 \mathrm{H}]^{2+}$, again led to dramatic changes in the ${ }^{1} \mathrm{H}$ NMR spectra. Most strikingly, the signals of the aromatic viologen protons $\mathrm{H}_{\mathrm{a}}$ and $\mathrm{H}_{\mathrm{b}}$ shifted downfield: by $+1.69 \mathrm{ppm}$ and $+2.71 \mathrm{ppm}$, respectively. These resonances are, however, at higher field $\left(\mathrm{H}_{\mathrm{a}}\right.$ at $7.81 \mathrm{ppm}$ and $\mathrm{H}_{\mathrm{b}}$ at $7.67 \mathrm{pm}$ ) than expected in an uncomplexed viologen. This is explained by assuming that the short C5-spacer and the blocking group prevent the viologen from completely leaving the porphyrin host, whereas the viologen can completely slide away from the porphyrin moiety in $[2]$ catenane $[6 \cdot 2 \mathrm{H}]^{2+}$. Also in the case of $[\mathbf{1 8} \cdot 2 \mathrm{H}]^{2+}$, a symmetrical NMR spectrum was observed, indicative of a movement of the porphyrin clip over the viologen moiety between the two blocking groups, which is fast on the NMR time scale at room temperature. This dynamic behavior was confirmed by VT-NMR experiments (Figure 5), in which the temperature dependence of the resonances $\mathrm{H}_{\mathrm{g}}$ of the side-wall of the porphyrin host, and both resonances $\mathrm{H}_{h}$ and $\mathrm{H}_{\mathrm{i}}$ of the blocking group are displayed.

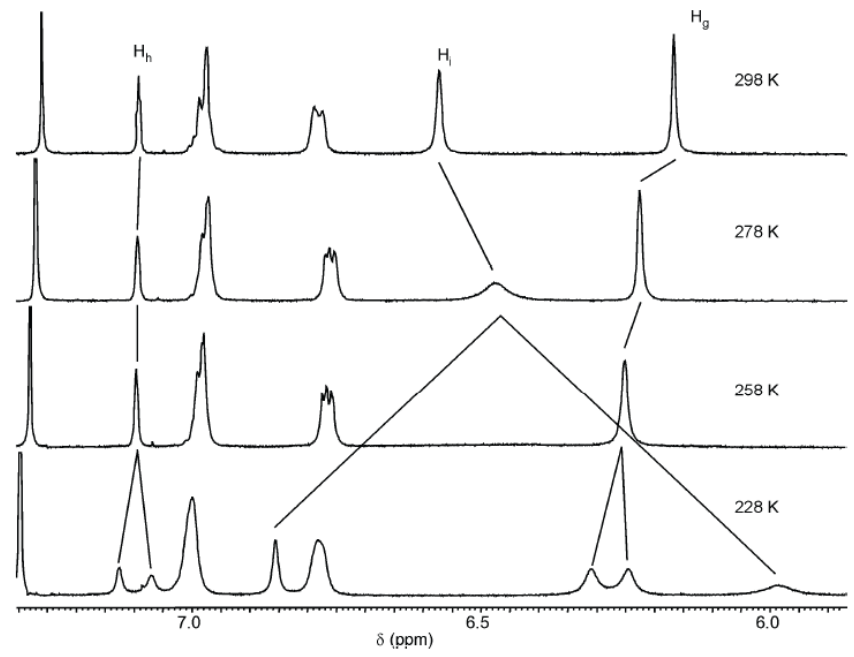

Figure 5. Parts of the VT-NMR spectra $(500 \mathrm{MHz})$ of protonated [2]rotaxane $[\mathbf{1 8} \cdot 2 \mathrm{H}]^{2+}$ See Scheme 5 for proton numbering.

As is shown in Figure 5, the signals $\mathrm{H}_{\mathrm{h}}$ and $\mathrm{H}_{\mathrm{i}}$ of the blocking group split up into a downfield and upfield-shifted signal, which is a consequence of shielding effects of the porphyrin on the protons that are nearest to it. We propose that the porphyrin also reduces the conformational freedom of these protons, since the upfield signals are somewhat broadened. Similar to what was observed in the VTNMR study of the $[2]$ catenane $[6 \cdot 2 \mathrm{H}]^{2+}$, new resonances appeared below $0 \mathrm{ppm}$, which are assigned to the aliphatic spacer protons that are situated inside the cavity (vide infra). It is therefore proposed that protonated [2]rotaxane $[\mathbf{1 8} \cdot 2 \mathrm{H}]^{2+}$ shuttles between the two degenerate states that are created due to the unfavourable electrostatic interactions between the doubly charged viologen moiety and the protonated porphyrin (Scheme 7).
Scheme 7. Switching between two degenerate states in $[2]$ rotaxanes $[\mathbf{1 8 - 2 0} \cdot 2 \mathrm{H}]^{2+}$, as determined by VT-NMR

The dynamic behaviour of protonated rotaxanes $[\mathbf{1 9} \cdot 2 \mathrm{H}]^{2+}$ and $[20 \cdot 2 \mathrm{H}]^{2+}$ was also investigated by VT-NMR. These complexes were found to display a similar dynamic motion, however, the increased spacer length between the viologen moiety and the blocking group had a remarkable effect on the Gibbs energy barrier associated with the shuttling motion when compared to the shorter spaced rotaxane $[\mathbf{1 8} \cdot 2 \mathrm{H}]^{2+}$ (Table 2). This is most clearly exemplified in Figure 6, which shows the 0 to -4 ppm region of the ${ }^{1} \mathrm{H}$ NMR spectra of $[\mathbf{1 9} \cdot 2 \mathrm{H}]^{2+}$ and $[\mathbf{2 0} \cdot 2 \mathrm{H}]^{2+}$. At $298 \mathrm{~K}$, the shuttling between the two degenerate states in $[\mathbf{1 9} \cdot 2 \mathrm{H}]^{2+}$ is fast on the NMR timescale, leading to a highly symmetrical spectrum that shows no resonances in this upfield region. If the temperature is lowered to $238 \mathrm{~K}$, signals originating from the aliphatic spacer protons of the thread inside the cavity become visible between 0 and $-4 \mathrm{ppm}$ as a result of the fact that the exchange between the two degenerate states has now become slow on the NMR timescale. In marked contrast, the ${ }^{1} \mathrm{H}$ NMR spectrum of $[\mathbf{2 0} \cdot 2 \mathrm{H}]^{2+}$ already shows similar signals in this region at $298 \mathrm{~K}$, indicating that the Gibbs energy barrier associated with the dynamic motion must be higher than that for the shorter-spaced rotaxanes. We therefore conclude that the Gibbs energy of activation for the shuttling process becomes higher as the spacer length increases. The thermodynamic parameters for the shuttling processes involving the [2]rotaxanes $[\mathbf{1 8 - 2 0} \cdot 2 \mathrm{H}]^{2+}$, as determined by the coalescence method, are summarized in Table 2.

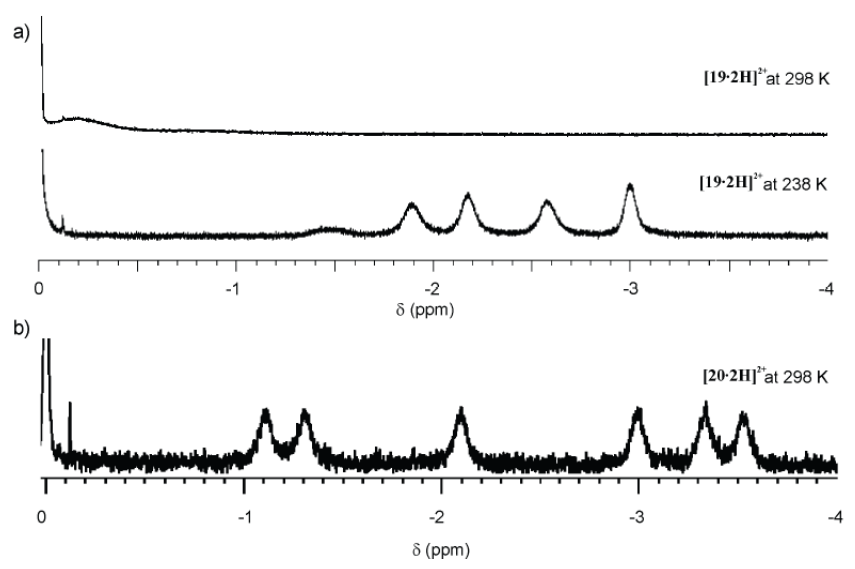

Figure 6. (a) Parts of the ${ }^{1} \mathrm{H}$ NMR spectra $(500 \mathrm{MHz})$ of [2]rotaxane $[\mathbf{1 9} \cdot 2 \mathrm{H}]^{2+}$ at $298 \mathrm{~K}$ and $238 \mathrm{~K}$ and (b) [2]rotaxane $[\mathbf{2 0} \cdot 2 \mathrm{H}]^{2+}$ at $298 \mathrm{~K}$, showing that at $298 \mathrm{~K}$ the shuttling equilibrium is fast on the NMR timescale for $[\mathbf{1 9} \cdot 2 \mathrm{H}]^{2+}$ and slow for $[\mathbf{2 0} \cdot 2 \mathrm{H}]^{2+}$

Table 2 Thermodynamic and kinetic data for the shuttling process in protonated [2]rotaxanes $[\mathbf{1 8 - 2 0} \cdot 2 \mathrm{H}]^{2+.}$.

\begin{tabular}{ccccc}
\hline Rotaxane & Probe proton & $T_{\mathrm{c}}(\mathrm{K})^{[\mathrm{a}]}$ & $k_{\mathrm{c}}\left(\mathrm{s}^{-1}\right)$ & $\Delta G_{\mathrm{c}}^{\ddagger}\left(\mathrm{kJ} \mathrm{mol}^{-1}\right)^{[\mathrm{b}]}$ \\
\hline$[\mathbf{1 8} \cdot 2 \mathrm{H}]^{2+}$ & $i$ & 258 & 970 & 48 \\
{$[\mathbf{1 9} \cdot 2 \mathrm{H}]^{2+}$} & $a$ & 244 & 62 & 51 \\
{$[\mathbf{2 0} \cdot 2 \mathrm{H}]^{2+}$} & $g$ & 302 & 71 & 63
\end{tabular}

${ }^{[a]}$ Coalescence temperature. ${ }^{[b]}$ Estimated error $10 \%$. For proton numbering see Schemes 2 and 5.
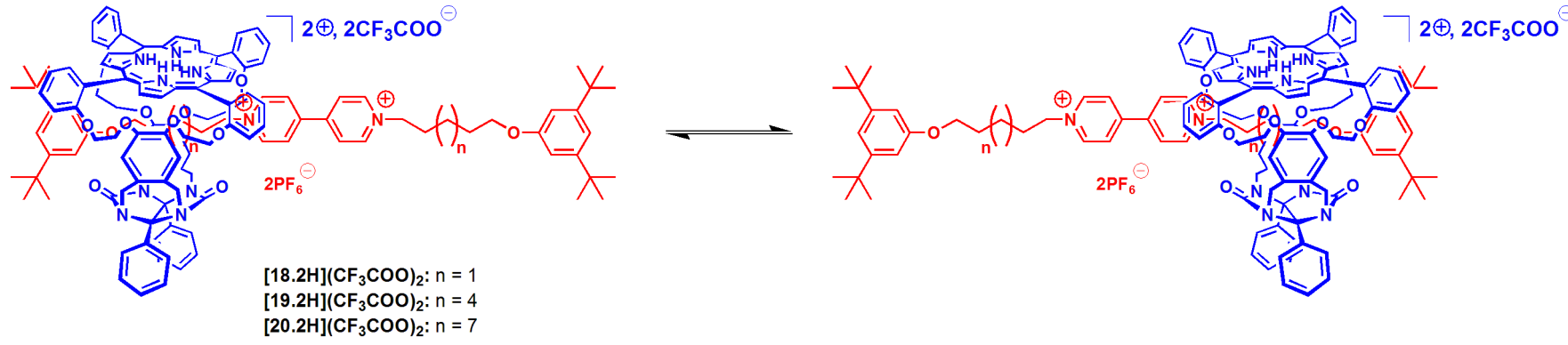
It should be noted that these values are not determined at the same temperature, so a detailed comparison between the $\Delta G_{\mathrm{c}}^{\ddagger}$ values is not really allowed. Unfortunately, the activation parameters $\Delta H^{\star}$ and $\Delta S^{\ddagger}$ could not be determined, as the quality of the spectra was not good enough for a line shape analysis. However, we tentatively conclude that the energy barrier associated with the shuttling process increases as the spacer length increases. This can be explained by assuming that in the case of a longer spacer, the doubly charged porphyrin host can slide away further from the doubly charged viologen moiety, thereby lowering the energies of the two degenerate states associated with the shuttling process, because the electrostatic repulsion is reduced. Based on these observations we propose that the porphyrin in $[2]$ catenane $[6 \cdot 2 \mathrm{H}]^{2+}$ shuttles between the two oxygen atoms and moves predominantly over the alkene part and not over the viologen, due to unfavourable electrostatic interactions. This behaviour is in marked contrast with the circumrotational movement of a similar [2]catenane, observed by Gunter et al. ${ }^{[15]}$ It is thus possible to induce a shuttling motion of the porphyrin host across the circular thread in [2]catenane 6 by simply protonating the porphyrin pyrrole nitrogen atoms. We also made attempts to investigate the dynamic behaviour of the large molecular necklaces $\mathbf{1 0}$ and 11. Unfortunately, complicated NMR spectra were observed in which the proton signals could not be assigned.

In a final series of experiments we studied the photophysical properties of the interlocked complexes. We first studies [2]catenane $[\mathbf{6} \cdot 2 \mathrm{H}]^{2+}$ by means of UV/Vis and fluorescence spectroscopy. Addition of an excess of TFA (5 vol\%) to a $\mathrm{CHCl}_{3}$ solution of [2]catenane $\mathbf{6}\left([\mathbf{6}] \sim 10^{-6} \mathrm{M}\right)$ revealed a red shift of the Soret band from $\lambda_{\max }=421 \mathrm{~nm}$ to $\lambda_{\max }=437 \mathrm{~nm}$, accompanied with significant broadening, which is a spectral change that is generally observed for protonation of simple porphyrins (Figure 7a). The fluorescence spectrum of $\mathbf{6}$ in $\mathrm{CHCl}_{3}$ changed dramatically upon protonation of the porphyrin. Whereas in $\mathbf{6}$ no detectable fluorescence emission could be observed upon excitation at $\lambda_{\max }=421 \mathrm{~nm}$, due to efficient fluorescence quenching by the viologen inside the cavity, a large fluorescence emission peak at $\lambda_{\mathrm{em}}=643 \mathrm{~nm}$ emerged upon addition of TFA and excitation at $\lambda_{\max }=437 \mathrm{~nm}$ (Figure 7b).
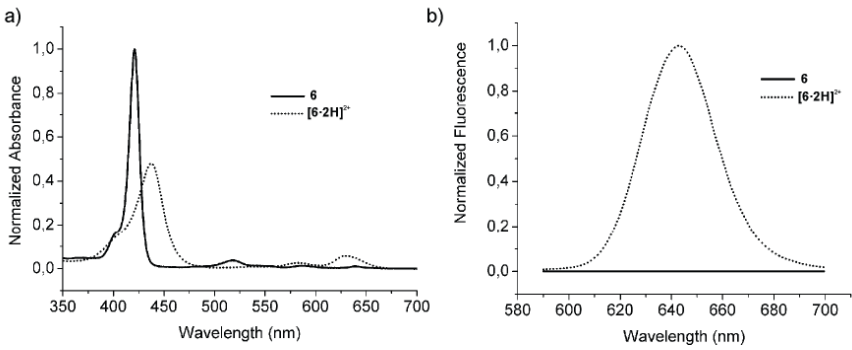

Figure 7. UV/Vis (a) and fluorescence (b) spectra of [2]catenanes 6 and $[6 \cdot 2 \mathrm{H}]^{2+}$.

Since upon protonation of the porphyrin the viologen moiety is expelled from the cavity, it can no longer act as a quencher, resulting in a dramatic increase in porphyrin fluorescence. The addition of pyridine to the solution resulted in deprotonation of $[6 \cdot 2 \mathrm{H}]^{2+}$, regenerating 6 , as well as the previously observed UV/Vis and fluorescence spectra, indicating the reversible nature of the switching process. This result clearly demonstrates that [2]catenane $\mathbf{6}$ can be switched between a non-fluorescent and a fluorescent state, using simple acid-base chemistry. ${ }^{[18]}$ Rotaxanes 18-20 were also protonated and their fluorescence spectra recorded. Figure 8 a shows the UV/Vis spectra of protonated catenane $[6 \cdot 2 \mathrm{H}]^{2+}$ and protonated rotaxanes $[\mathbf{1 8 - 2 0} \cdot 2 \mathrm{H}]^{2+}$.

The protonated rotaxanes exhibit a broader Soret band than the one observed for the protonated catenane. This effect may be related to the different geometries of the two types of structures and the different types of interactions between the porphyrin and viologen moieties resulting from this. The fluorescence spectra display some interesting features (Figure 8b). Although $[\mathbf{1 8 - 2 0} \cdot 2 \mathrm{H}]^{2+}$ display fluorescence emission upon excitation, the observed fluorescence intensities are much lower than the emission intensity originating from catenane $[6 \cdot 2 \mathrm{H}]^{2+}$. Moreover, a clear spacer length effect on the fluorescence intensity is observed: if the length of the rotaxane thread increases, the fluorescence emission also increases. This can be explained by assuming that when the distance between the viologen moiety and the porphyrin clip is larger, the viologen moiety is less efficient in quenching the porphyrin's fluorescence.
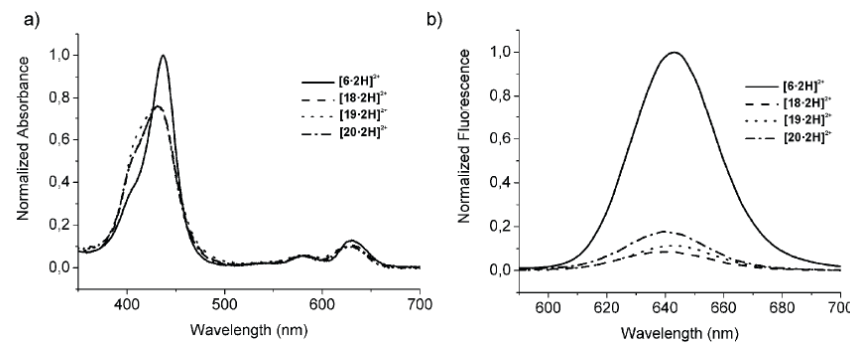

Figure 8. UV/Vis (a) and fluorescence (b) spectra of $[6 \cdot 2 \mathrm{H}]^{2+}$ and protonated rotaxanes $[18-20 \cdot 2 \mathrm{H}]^{2+}$

\section{Conclusion}

We have demonstrated that catenanes and molecular necklaces based on porphyrin $\mathbf{1}$ and bis-olefin-terminated viologens can be easily synthesized in high yields using an olefin metathesis protocol. The size of the olefin substituents of the viologens has a marked effect on the products of the ring-closing reaction. Whereas a viologen with long substituents (21 atoms) yields a [2]catenane and a [3]catenane, the viologen with shorther substituents (8 atoms) gives a mixture of a [3]catenane, a [4]molecular necklace, a [5]molecular necklace and higher oligomers, from which the [4]molecular necklace and [5]molecular necklace could be isolated. In addition, several [2]rotaxanes with threads of different lengths were successfully synthesized by $\mathrm{SN}_{2}$-type reactions. The interlocked [2]catenane and [2]rotaxane structures show interesting switching behaviour: a shuttling motion of the porphyrin in the described catenane and rotaxanes can be turned on and off using acid and base stimuli. The protonated porphyrin host in the [2]catenane shuttles between two oxygen atoms predominantly by a route via the carbon-carbon double bond in the aliphatic ring, because the cationically charged viologen moiety poses a severe electrostatic barrier. In the case of the protonated [2]rotaxanes, the energy barrier associated with the shuttling is length-dependent: when the spacer length between the viologen moiety and the blocking group of the thread is increased, the energy barrier also increases. The induction of motion of the porphyrin moiety in the [2]catenane and [2]rotaxanes is also accompanied by interesting photophysical changes. Upon protonation of the [2]catenane, the viologen that quenches the porphyrin fluorescence is expelled from the cavity, resulting in a dramatic increase in the fluorescence emission. Similar effects were observed for the [2]rotaxanes, but not as dramatic as in the case of the [2]catenane, and a clear dependency of the fluorescence properties on the length of the spaced between the viologen and the blocking group was observed.

Following the protocols described in this paper we are currently planning the synthesis of functional catenane structures derived from metal-porphyrin (metal is $\mathrm{Zn}$ or $\mathrm{Mn}$ ) containing glycoluril compounds. These will be allowed to form double cage compounds with other glycoluril derivatives as schematically shown in Figure 1. 
The study of the properties of these systems as a first step towards a molecular Turing machine is envisaged.

\section{Experimental Section}

Materials and methods. Tetrahydrofuran was distilled under nitrogen from sodium and benzophenone. Acetonitrile was distilled under nitrogen from calcium hydride. Chloroform was distilled under nitrogen from calcium chloride. $n$-Hexane was distilled under nitrogen from sodium. Dimethylformamide was dried over $\mathrm{BaO}$ for one week and then vacuum distilled. The first $30 \%$ of the distillate was discarded. All other solvents and chemicals were either commercially available and used without further purification. Compounds $\mathbf{1 2}$ and $\mathbf{1 5}$ were synthesized as described previously. ${ }^{[\mathrm{REF}]}$ BioRad Biobeads (SX-1) were used for size exclusion chromatography. Silica 60 (Merck) was used fo column chromatography. Fluorescence experiments were performed on a Perkin Elmer LS50B luminescence spectrometer equipped with a thermostatted cuvette holder. UV/Vis spectra were recorded on a Varian Cary 50 Conc spectrometer. ${ }^{1} \mathrm{H}$ NMR spectra were recorded on a Bruker DPX-200, AM-300 or Bruker DRX-500 spectrometers. Chemical shifts are reported in ppm downfield from internal tetramethylsilane $(0.00$ $\mathrm{ppm})$ in the case of ${ }^{1} \mathrm{H}$ NMR spectra in $\mathrm{CDCl}_{3}$ or $\mathrm{CDCl}_{3} / \mathrm{CD}_{3} \mathrm{CN}(1: 1, \mathrm{v} / \mathrm{v})$, otherwise the solvent peak was used as a reference $\left(\mathrm{CD}_{3} \mathrm{CN}\right.$ : $\left.1.94 \mathrm{ppm}\right)$. MALDI-TOF mass spectra were recorded on a Bruker Biflex III spectrometer using dithranol as a matrix.

\section{Syntheses}

10-(10-Bromodecyloxy)dec-1-ene (2). Under an argon atmosphere, dec-9-en-1-ol (1.4 g, 9 mmole) was added to a mixture of $\mathrm{NaH}(384 \mathrm{mg}, 9.6$ mmole, $60 \%$ dispersion in mineral oil) in argon-purged THF $(15 \mathrm{ml})$. After the evolution of hydrogen gas had ceased, 1,10-dibromodecane ( $16.1 \mathrm{~g}, 53.6 \mathrm{mmole})$ was added and the resulting mixture was stirred for 5 days. The solvent was removed by rotary evaporation, after which the resulting crude product was dissolved in $\mathrm{Et}_{2} \mathrm{O}$. This solution was washed with water dried $\left(\mathrm{MgSO}_{4}\right)$, filtrated and evaporated to dryness. The residue was purified by column chromatography (silica, $n$-hexane - EtOAc/ $n$-hexane $(0.7: 100, v / v)$ ) to yield $\mathbf{2}$ as a clear, colourless oil $(1.5 \mathrm{~g}, 44 \%) .{ }^{1} \mathrm{H} \mathrm{NMR}\left(\mathrm{CDCl}_{3}, 200 \mathrm{MHz}\right) \delta 5.90-5.70\left(\mathrm{~m}, 1 \mathrm{H}, \mathrm{H}_{2} \mathrm{C}=\mathrm{CH}\right)$, 5.03-4.88 (m, $\left.2 \mathrm{H}, \mathrm{H}_{2} \mathrm{C}=\mathrm{CH}\right), 3.45-3.33\left(\mathrm{~m}, 6 \mathrm{H}, \mathrm{CH}_{2} \mathrm{OCH}_{2}\right.$ and $\left.\mathrm{CH}_{2} \mathrm{Br}\right), 2.04(\mathrm{q}, 2 \mathrm{H}$, $\left.\mathrm{H}_{2} \mathrm{C}=\mathrm{CHCH}_{2},{ }^{3} \mathrm{~J}=7.0 \mathrm{~Hz}\right), 1.69-1.20\left(\mathrm{~m}, 28 \mathrm{H}, \mathrm{CH}_{2}\right) \mathrm{ppm}$

$\left(N, N^{\prime}\right)$-Di-(1-(10-(dec-9-enyloxy)decyl)-4,4'-bipyridinium dihexafluorophosphat (3). A mixture of 4,4'-bipyridine (102 mg, $0.65 \mathrm{mmole})$ and 2 ( $1.23 \mathrm{~g}, 3.3 \mathrm{mmole})$ in DMF ( $1 \mathrm{ml}$ ) was stirred overnight under a $\mathrm{N}_{2}$ atmosphere at $1000 \mathrm{C}$. After cooling, $\mathrm{Et}_{2} \mathrm{O}$ was added and the resulting precipitate was filtered and washed with $\mathrm{Et}_{2} \mathrm{O}$ and $\mathrm{MeCN}$. The solid was dissolved in $\mathrm{MeCN} / \mathrm{H}_{2} \mathrm{O}(1: 1, \mathrm{v} / \mathrm{v})$ after which the addition of a saturated solution of $\mathrm{NH}_{4} \mathrm{PF}_{6}$ in $\mathrm{H}_{2} \mathrm{O}$ resulted in the precipitation of 3 . The solid was recrystallized from hot $\mathrm{MeOH}$ and washed with $\mathrm{MeOH}$ and $\mathrm{Et}_{2} \mathrm{O}$ to give 3 as a white solid $(153 \mathrm{mg}, 23 \%) .1 \mathrm{H} \mathrm{NMR}\left(\mathrm{CDCl}_{3} / \mathrm{CD}_{3} \mathrm{CN}(1: 1, \mathrm{v} / \mathrm{v}), 200 \mathrm{MHz}\right) \delta 8.90(\mathrm{~d}, 4 \mathrm{H}$ BipyH, $\left.{ }^{3} \mathrm{~J}=7.0 \mathrm{~Hz}\right), 8.40\left(\mathrm{~d}, 4 \mathrm{H}, \mathrm{BipyH},{ }^{3} \mathrm{~J}=7.0 \mathrm{~Hz}\right), 5.93-5.70\left(\mathrm{~m}, 2 \mathrm{H}, \mathrm{H}_{2} \mathrm{C}=\mathrm{CH}\right)$ 5.05-4.86 (m, 4H, $\left.\mathrm{H}_{2} \mathrm{C}=\mathrm{CH}\right), 4.61\left(\mathrm{t}, 4 \mathrm{H}, \mathrm{BipyCH}_{2},{ }^{3} \mathrm{~J}=6.4 \mathrm{~Hz}\right), 3.36\left(\mathrm{t}, 8 \mathrm{H}, \mathrm{CH}_{2} \mathrm{O},{ }^{3} \mathrm{~J}\right.$ $=6.4 \mathrm{~Hz}), 2.02\left(\mathrm{q}, 4 \mathrm{H}, \mathrm{H}_{2} \mathrm{C}=\mathrm{CHCH}_{2},{ }^{3} \mathrm{~J}=7.0 \mathrm{~Hz}\right), 1.60-1.20\left(\mathrm{~m}, 56 \mathrm{H}, \mathrm{CH}_{2}\right) \mathrm{ppm}$ MALDI-TOF: $m / z 746\left(\mathrm{M}-2 \mathrm{PF}_{6}\right)^{+}$

( $\left.N, N^{\prime}\right)$-Di-(1-(oct-7-enyl))-4,4'-bipyridinium dihexafluorophosphate (4). A mixture of 4,4'-bipyridine ( $100 \mathrm{mg}, 0.64 \mathrm{mmole})$ and 8 -bromo-octene $(1.2 \mathrm{~g}, 6.3 \mathrm{mmole})$ in DMF $(1 \mathrm{ml})$ was stirred overnight under a $\mathrm{N}_{2}$ atmosphere at $100^{\circ} \mathrm{C}$. After cooling, $\mathrm{Et}_{2} \mathrm{O}$ was added and the resulting precipitate was filtered and washed with $\mathrm{Et}_{2} \mathrm{O}$ and $\mathrm{MeCN}$. The solid was dissolved in MeCN and a saturated solution of NH4PF6 in $\mathrm{H} 2 \mathrm{O}$ was added, which resulted in the precipitation of 4 as a white solid in a yield of $260 \mathrm{~ms}$ $(61 \%) .{ }^{1} \mathrm{H}$ NMR $\left(\mathrm{CD}_{3} \mathrm{CN}, 200 \mathrm{MHz}\right) \delta 8.91\left(\mathrm{~d}, 4 \mathrm{H}, \mathrm{BipyH},{ }^{3} \mathrm{~J}=6.9 \mathrm{~Hz}\right), 8.39(\mathrm{~d}, 4 \mathrm{H}$ BipyH, $\left.{ }^{3} \mathrm{~J}=6.9 \mathrm{~Hz}\right), 5.95-5.73\left(\mathrm{~m}, 2 \mathrm{H}, \mathrm{H}_{2} \mathrm{C}=\mathrm{CH}\right), 5.11-4.89\left(\mathrm{~m}, 4 \mathrm{H}, \mathrm{H}_{2} \mathrm{C}=\mathrm{CH}\right), 4.61(\mathrm{t}$ $\left.4 \mathrm{H}, \mathrm{BipyCH}_{2}, 3 \mathrm{~J}=7.4 \mathrm{~Hz}\right), 2.08\left(\mathrm{~m}, 8 \mathrm{H}, \mathrm{CH}_{2}\right), 1.39$ (bs, 12H, $\left.\mathrm{CH}_{2}\right)$ ppm. MALDITOF: $m / z 378\left(\mathrm{M}-2 \mathrm{PF}_{6}\right)^{+}$

[2]Catenane 6 and [3]catenane 7. A solution of $\mathbf{1}(40 \mathrm{mg}, 0.03 \mathrm{mmole})$ in a minimal amount of $\mathrm{CHCl}_{3}$ and a solution of $\mathbf{3}(30.8 \mathrm{mg}, 0.03 \mathrm{mmole})$ in a minimal amount of acetone were mixed, and the solvent was evaporated. The resulting solid was dissolved in a minimal amount of $\mathrm{CH}_{2} \mathrm{Cl}_{2}$ and precipitated in $n$-hexane. After drying in vacuo, the thus obtained [2]pseudorotaxane 5 was dissolved in $\mathrm{CH}_{2} \mathrm{Cl}_{2}(60 \mathrm{ml})$, and the firs generation Grubbs' catalyst $(5 \mathrm{mg}, 6.1 \mu \mathrm{mole})$ was added under an argon atmosphere. The resulting mixture was stirred overnight at room temperature, after which the solven was removed by rotary evaporation. The crude mixture was subjected to column chromatography (silica, $\mathrm{CH}_{2} \mathrm{Cl}_{2} / \mathrm{MeNO}_{2} / \mathrm{MeOH}, 8: 1: 1, v / v / v$ ) yielding a mixture of $\mathbf{1}$, 6 and 7. These compounds were separated by column chromatography (first column: biobeads, $\mathrm{CH}_{2} \mathrm{Cl}_{2}$; second column: silica, $1-5 \mathrm{vol} \% \mathrm{MeOH} / \mathrm{CH}_{2} \mathrm{Cl}_{2}$ ) to yield 6 (48 mg, $69 \%)$ and $7(2 \mathrm{mg}, 3 \%)$ as purple solids. 6: ${ }^{1} \mathrm{H} \mathrm{NMR}\left(\mathrm{CDCl}_{3}, 500 \mathrm{MHz}\right): \delta 9.08(\mathrm{~s}, 4 \mathrm{H}$, H12), 8.79 (s, 4H, H13), 8.11 (dd, 4H, H11, ${ }^{3} \mathrm{~J}=7.3 \mathrm{~Hz},{ }^{5} \mathrm{~J}=1.5 \mathrm{~Hz}$ ), 7.84 (dt, 4H, H10 $\left.{ }^{3} \mathrm{~J}=8.0 \mathrm{~Hz},{ }^{5} \mathrm{~J}=1.6 \mathrm{~Hz}\right), 7.47\left(\mathrm{t}, 4 \mathrm{H}, \mathrm{H} 9,{ }^{3} \mathrm{~J}=7.5 \mathrm{~Hz}\right), 7.42\left(\mathrm{~d}, 4 \mathrm{H}, \mathrm{H} 8,{ }^{3} \mathrm{~J}=8.4 \mathrm{~Hz}\right)$ 7.05-6.97 (m, 6H, H1,2), 6.95-6.90 (m, 4H, H3), $6.18\left(\mathrm{~d}, 4 \mathrm{H}, \mathrm{Hb},{ }^{3} \mathrm{~J}=4.8 \mathrm{~Hz}\right), 6.08(\mathrm{~s}$ 4H, H5), 4.93 (m, Hu, cis), 4.87 (m, Hu, trans), 4.79 (d, 4H, Ha, $\left.{ }^{3} \mathrm{~J}=4.4 \mathrm{~Hz}\right), 4.35(\mathrm{~m}$ $4 \mathrm{H}, \mathrm{H} 7), 4.28\left(\mathrm{~d}, 4 \mathrm{H}, \mathrm{H} 4,{ }^{2} \mathrm{~J}=16.0 \mathrm{~Hz}\right), 4.04(\mathrm{~m}, 4 \mathrm{H}, \mathrm{H} 7), 3.74\left(\mathrm{~d}, 4 \mathrm{H}, \mathrm{H} 4,{ }^{2} \mathrm{~J}=15.8\right.$ Hz), 3.52 (m, 4H, H6), 3.48 (m, 8H, Hl, m), 3.44 (m, 4H, Hc), 2.78 (m, 4H, H6), 1.67 $(\mathrm{m}, 8 \mathrm{H}, \mathrm{Hk}, \mathrm{n}), 1.60(\mathrm{~m}, \mathrm{Ht}$, cis $), 1.50(\mathrm{~m}, 8 \mathrm{H}, \mathrm{Ho}, \mathrm{j}), 1.46(\mathrm{~m}, \mathrm{Ht}$, trans $), 1.30(\mathrm{~m}, 8 \mathrm{H}$ $\mathrm{He}, \mathrm{f}), 1.20$ (m, 8H, Hi,p), 1.08 (m, 8H, Hh,q), 0.96 (m, 8H, Hg,r), 0.92 (m, Hs, cis), $0.87(\mathrm{~m}, \mathrm{Hs}$, trans $),-2.81(\mathrm{~s}, 2 \mathrm{H}, \mathrm{H} 14) \mathrm{ppm}$. MALDI-TOF: $\mathrm{m} / z 2064\left(\mathrm{M}-2 \mathrm{PF}_{6}\right)^{+} .7:{ }^{1} \mathrm{H}$ $\mathrm{NMR}\left(\mathrm{CDCl}_{3}, 500 \mathrm{MHz}\right.$ ) (for proton numbering see Figure 1 and Schemes 1 and 2): $\delta$ 9.02 (s, 8H, H12), 8.65 (s, 8H, H13), 8.02 (dd, 8H, H11, $\left.{ }^{3} \mathrm{~J}=7.3 \mathrm{~Hz},{ }^{5} \mathrm{~J}=1.7 \mathrm{~Hz}\right), 7.81$ (dt, 8H, H10, $\left.{ }^{3} \mathrm{~J}=8.0 \mathrm{~Hz},{ }^{5} \mathrm{~J}=1.5 \mathrm{~Hz}\right), 7.45-7.35(\mathrm{~m}, 16 \mathrm{H}, \mathrm{H} 9,10), 7.10-6.90(\mathrm{~m}, 20 \mathrm{H}$, $\mathrm{H} 1,2,3), 6.05$ (bs, 8H, Hb), 5.88 (bs, 8H, H5), 5.44-5.35 (m, 4H, Hu), 4.62 (bs, 8H, Ha), 4.30-4.21 (m, 8H, H7), $4.16\left(\mathrm{~d}, 8 \mathrm{H}, \mathrm{H} 4,{ }^{2} \mathrm{~J}=15.9 \mathrm{~Hz}\right), 3.88-3.75(\mathrm{~m}, 8 \mathrm{H}, \mathrm{H} 7), 3.60(\mathrm{~d}$, $\left.8 \mathrm{H}, \mathrm{H} 4,{ }^{2} \mathrm{~J}=16.0 \mathrm{~Hz}\right), 3.52-3.43(\mathrm{~m}, 16 \mathrm{H}, \mathrm{Hl}, \mathrm{m}), 3.40-3.20$ (m, $\left.16 \mathrm{H}, \mathrm{Hc}, 6\right), 2.66-2.55$ (m, 8H, H6), 2.10-0.70 (m, $\mathrm{CH}_{2}$ ), -2.95 (s, 4H, H14) ppm. MALDI-TOF: $\mathrm{m} / \mathrm{z}$ 4128, $4273,4415,4560\left[\mathrm{M}-\mathrm{nPF}_{6}\right]^{+}(\mathrm{n}=1-4), 2064\left(\mathrm{M}-4 \mathrm{PF}_{6}\right)^{2+}$

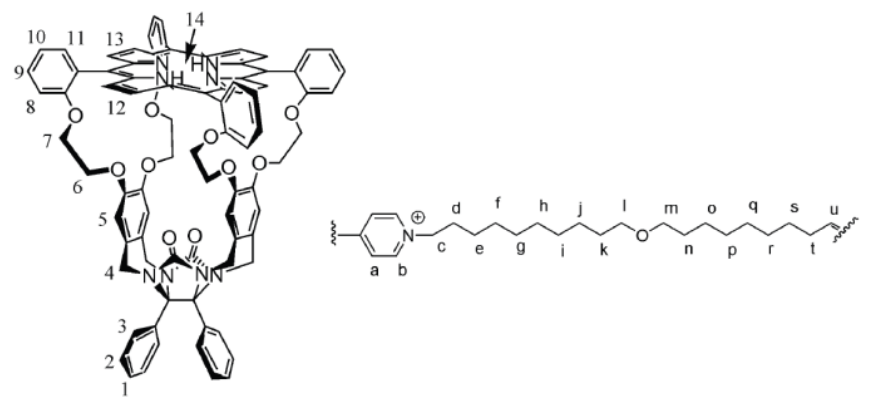

[4]Molecular necklace 10 and [5]molecular necklace 11. A solution of 1 (45.6 mg, $0.034 \mathrm{mmole})$ in a minimal amount of $\mathrm{CHCl}_{3}$ and a solution of $4(20.7 \mathrm{mg}, 0.031$ mmole) in a minimal amount of acetone were mixed, and the solvent was evaporated. The resulting solid was dissolved in a minimal amount of $\mathrm{CH}_{2} \mathrm{Cl}_{2}$ and precipitated in $n$ hexane. After drying in vacuo, the thus obtained [2]pseudorotaxane $\mathbf{8}$ was dissolved in $\mathrm{CH}_{2} \mathrm{Cl}_{2}$ (34 ml), $2 \mathrm{mg}$ of first generation Grubbs' catalyst was added, and the resulting solution was refluxed under an argon atmosphere. After $30 \mathrm{~min}$., another $2 \mathrm{mg}$ of Grubbs' catalyst was added and refluxing was continued for 6 hrs after which a last portion of $0.5 \mathrm{mg}$ Grubbs' catalyst was added (total added catalyst: $4.5 \mathrm{mg}, 5.5 \mu \mathrm{mole}$ ). After an additional hour of refluxing, the solution was allowed to cool and a drop of ethylvinyl ether was added after which the solvent was evaporated. The crude mixture was subjected to column chromatography (silica, $\mathrm{CH}_{2} \mathrm{Cl}_{2} / \mathrm{MeNO}_{2} / \mathrm{MeOH}, 8: 1: 1$, $v / v / v)$ yielding a mixture of $\mathbf{1}, \mathbf{9}, \mathbf{1 0}, \mathbf{1 1}$ and higher molecular necklace oligomers. This mixture was subjected to size exclusion chromatography (biobeads, $\mathrm{CH}_{2} \mathrm{Cl}_{2}$ ) from which the [4]molecular necklace $\mathbf{1 0}$ and the [5]molecular necklace $\mathbf{1 1}$ could be isolated. Both compounds were subjected to another size exclusion column to give $\mathbf{1 0}$ (12 mg, $18 \%)$ and $11(7 \mathrm{mg}, 11 \%)$ as purple solids. The ${ }^{1} \mathrm{H}$ NMR spectra were assigned based on $2 \mathrm{D}$ COSY and 2D-NOESY spectra. Therefore, some values for the integrals and signal shapes are not given. 10: ${ }^{1} \mathrm{H}$ NMR $\left(\mathrm{CDCl}_{3}, 500 \mathrm{MHz}\right) \delta 9.07(\mathrm{~m}, 12 \mathrm{H}, \mathrm{H} 12), 8.72$ $(\mathrm{m}, 12 \mathrm{H}, \mathrm{H} 13), 8.06(\mathrm{~m}, 12 \mathrm{H}, \mathrm{H} 11), 7.82(\mathrm{~m}, 12 \mathrm{H}, \mathrm{H} 10), 7.44(\mathrm{~m}, 24 \mathrm{H}, \mathrm{H} 8,9), 7.1-6.6$ (m, 30H, H1 2,3), 6.54 (bs, BipyH), 6.42 (bs, BipyH), 6.2-5.8 (m, BipyH), 6.05-5.9 (m, H5), 5.57 (bs, $\mathrm{CH}=\mathrm{CH}$, trans), 5.49 (bs, $\mathrm{CH}=\mathrm{CH}$, cis), 4.84 (bs, BipyH), 4.74 (bs, BipyH), 4.60 (bs, ВipyH), 4.53 (bs, BipyH), 4.40 (bs, BipyH), 4.29 (bs, H7), 4.19 (d, $\mathrm{H} 4,{ }^{2} \mathrm{~J}=15.8 \mathrm{~Hz}$ ), 4.05-3.8 (m, H7), 3.65-3.05 (m, BipyCH $\left.{ }_{2}\right), 3.45-3.30$ (m, H6), 2.802.40 (m, H6), 2.15 (bs, $\mathrm{CH}_{2} \mathrm{CH}=$, cis), 2.08 (bs, $\mathrm{CH}_{2} \mathrm{CH}=$, trans), 1.60-0.7 (m, $\left.\mathrm{CH}_{2}\right)$, $2.80--3.0(\mathrm{~m}, 6 \mathrm{H}, \mathrm{H} 14)$ ppm. MALDI-TOF: $\mathrm{m} / z$ 5088, 5234, 5378, $55235668 \mathrm{amu}$ $[\mathrm{M}-\mathrm{nPF} 6]^{+}(\mathrm{n}=2-6)$. 11: ${ }^{1} \mathrm{H}$ NMR $\left(\mathrm{CDCl}_{3}, 500 \mathrm{MHz}\right)$ (see Figure 1 for proton numbering) $\delta 9.07$ (app. d, 16H, H12), 8.77 (bs, 16H, H13), 8.07 (bs, 16H, H11), 7.83 (bm, 16H, H10), 7.45 (bm, 32H, H8,9), 7.10-6.65 (m, 40H, H1,2,3), 6.38 (bs, BipyH), 6.22 (bs, BipyH), 6.19 (bs, BipyH), 6.02 (bs, H5) 6.00 (bs, BipyH), 5.54 (bs, $\mathrm{CH}=\mathrm{CH}$, trans), 5.49 (bs, $\mathrm{CH}=\mathrm{CH}$, cis), 4.69 (BipyH), 4.65 (BipyH), 4.57 (ВipyH), 4.48 (ВipyH) 4.35 (bs, H7), 4.20 (m, H4), 4.02 (bs, H7), 3.56 (m, H4), 3.50-3.25 (m, BipyCH $_{2}$ ), 3.45 (bs, H6), 2.75 (bs, H6), $2.16\left(\mathrm{CH}_{2} \mathrm{CH}=\right.$, cis $), 2.09\left(\mathrm{CH}_{2} \mathrm{CH}=\right.$, trans $), 1.70-0.80\left(\mathrm{~m}, \mathrm{CH}_{2}\right)$, -2.87 (s, 8H, H14) ppm. MALDI-TOF: $m / z$ 7073, 7218, 7363, 7508, 7654, 7798 [M$\mathrm{nPF} 6]^{+}(\mathrm{n}=1-6)$.

1-(8-Bromooctyloxy)-3,5-di-tert-butylbenzene (13). A mixture of 3,5-di-tertbutylphenol ( $3 \mathrm{~g}, 14.5$ mmole), 1,8-dibromooctane ( $20 \mathrm{~g}, 73.5$ mmole $)$ and $\mathrm{K}_{2} \mathrm{CO}_{3}(10 \mathrm{~g}$ $72.4 \mathrm{mmole}$ ) in DMF (30 ml) was stirred overnight under an argon atmosphere, after which the solvent and the remaining 1,8-dibromooctane was distilled off. The resulting crude product was subjected to column chromatography (silica, $n$-hexane - EtOAc / $n$ hexane $(1: 9, \mathrm{v} / \mathrm{v}))$ to yield $\mathbf{1 3}$ as a colourless oil $(4.5 \mathrm{~g}, 78 \%) .{ }^{1} \mathrm{H}$ NMR $(\mathrm{CDCl} 3,200$ $\mathrm{MHz}) \delta 7.01(\mathrm{t}, 1 \mathrm{H}$, para-ArH, $4 \mathrm{~J}=1.7 \mathrm{~Hz}), 6.75(\mathrm{~d}, 2 \mathrm{H}$, ortho- $\mathrm{ArH}, 4 \mathrm{~J}=1.7 \mathrm{~Hz}), 3.96$ $\left(\mathrm{t}, 2 \mathrm{H}, \mathrm{OCH}_{2},{ }^{3} \mathrm{~J}=6.4 \mathrm{~Hz}\right), 3.39\left(\mathrm{t}, 2 \mathrm{H} \mathrm{CH} \mathrm{Cr}_{2},{ }^{3} \mathrm{~J}=6.9 \mathrm{~Hz}\right), 1.95-1.72\left(\mathrm{~m}, 4 \mathrm{H}, \mathrm{CH}_{2}\right)$, $1.57-1.23(\mathrm{~m}, 8 \mathrm{H}, \mathrm{CH} 2), 1.31$ (s, $\left.18 \mathrm{H}, \mathrm{CCH}_{3}\right) \mathrm{ppm}$

11-(3,5-Di-tert-butyl-phenoxy)-undecan-1-ol. 3,5-Di-tert-butylphenol (300 mg, 1.46 $\mathrm{mmol})$ and 11-bromoundecanol $(350 \mathrm{mg}, 1.39 \mathrm{mmol})$ were suspended in argon-flushed DMF $(10 \mathrm{~mL}) . \mathrm{K}_{2} \mathrm{CO}_{3}(750 \mathrm{mg}, 5.43)$ was added and the mixture was heated overnight at $100^{\circ} \mathrm{C}$ under argon. After cooling, the solvent was evaporated and the residue dissolved in $\mathrm{CH}_{2} \mathrm{Cl}_{2}$. The organic layer was washed first with aqueous $1 \mathrm{~N} \mathrm{HCl}$ and then with an aqueous saturated $\mathrm{NaHCO}_{3}$ solution. After evaporation of the solvent, the crude product was purified by column chromatography (Silica $60 \mathrm{H}, 5 \% \mathrm{EtOAc} / n$-hexane, v/v) to give the desired product as a white solid $(420 \mathrm{mg}, 77 \%) .{ }^{1} \mathrm{H} \mathrm{NMR}\left(\mathrm{CDCl}_{3}, 300 \mathrm{MHz}\right)$ $\delta 6.98\left(\mathrm{t}, 1 \mathrm{H}, \mathrm{ArH},{ }^{4} \mathrm{~J}=1.8 \mathrm{~Hz}\right), 6.73\left(\mathrm{~d}, 2 \mathrm{H}, \mathrm{ArH},{ }^{4} \mathrm{~J}=1.8 \mathrm{~Hz}\right), 3.94\left(\mathrm{t}, 2 \mathrm{H}, \mathrm{ArOCH}_{2},{ }^{3} \mathrm{~J}\right.$ $=6.6 \mathrm{~Hz}), 3.63\left(\mathrm{~m}, 2 \mathrm{H}, \mathrm{CH}_{2} \mathrm{OH}\right), 1.78\left(\mathrm{~m}, 2 \mathrm{H}, \mathrm{CH}_{2} \mathrm{CH}_{2} \mathrm{OH}\right), 1.7-1.1\left(\mathrm{~m}, 17 \mathrm{H} \mathrm{CH}_{2}\right.$ and $\mathrm{OH}), 1.31\left(\mathrm{~s}, 18 \mathrm{H}, \mathrm{CH}_{3}\right) \mathrm{ppm}$

1-(11-Bromoundecyloxy)-3,5-di-tert-butylbenzene (14). 11-(3,5-Di-tertbutylphenoxy)-undecan-1-ol (420 mg, $1.12 \mathrm{mmol})$ was dissolved in freshly distilled $\mathrm{CHCl}_{3}(15 \mathrm{~mL})$ under argon and this solution was cooled to $0^{\circ} \mathrm{C} . \mathrm{PBr}_{3}(0.5 \mathrm{~g}, 1.85$ $\mathrm{mmol}$ ) was added and the mixture was allowed to warm to room temperature and stirred 
overnight. Water was added dropwise to quench the reaction, and the mixture was extracted with aqueous $0.5 \mathrm{~N} \mathrm{NaOH}$. The organic layer was evaporated to dryness, and the residue was purified by column chromatography (Silica $60 \mathrm{H}, \mathrm{CHCl}_{3}$ ) to give 14 (305 mg, 62\%) as a white solid. ${ }^{1} \mathrm{H}$ NMR $\left(\mathrm{CDCl}_{3}, 300 \mathrm{MHz}\right) \delta 6.98\left(\mathrm{t}, 1 \mathrm{H}, \mathrm{ArH},{ }^{4} \mathrm{~J}=\right.$ $1.8 \mathrm{~Hz}), 6.72\left(\mathrm{~d}, 2 \mathrm{H}, \mathrm{ArH},{ }^{4} \mathrm{~J}=1.8 \mathrm{~Hz}\right), 3.94\left(\mathrm{t}, 2 \mathrm{H}, \mathrm{ArOCH}_{2},{ }^{3} \mathrm{~J}=6.6 \mathrm{~Hz}\right), 3.39(\mathrm{t}, 2 \mathrm{H}$ $\left.\mathrm{CH}_{2} \mathrm{Br},{ }^{3} \mathrm{~J}=6.5 \mathrm{~Hz}\right), 1.80\left(\mathrm{~m}, 4 \mathrm{H}, \mathrm{CH}_{2}\right), 1.6-1.2\left(\mathrm{~m}, 16 \mathrm{H}, \mathrm{CH}_{2}\right), 1.31\left(\mathrm{~s}, 18 \mathrm{H}, \mathrm{CH}_{3}\right) \mathrm{ppm}$ 1-(8-(3,5-Di-tert-butylphenoxy)octyl)-4,4'-bipyridin-1-ium hexafluorophosphate (16). 4,4'-Bipyridine (4 g, 25.6 mmole) and $\mathbf{1 3}$ (1 g, 2.5 mmole) were dissolved in $\mathrm{MeCN}(25 \mathrm{ml})$. The solution was refluxed overnight. After cooling $\mathrm{Et}_{2} \mathrm{O}$ was added and the resulting precipitate was filtered off and washed with $\mathrm{Et}_{2} \mathrm{O}$. The resulting gum was dissolved in hot water and a saturated aqueous solution of $\mathrm{NH}_{4} \mathrm{PF}_{6}$ was added resulting in the formation of an oil which solidified into a white solid upon scratching the inside of the flask. Filtration gave 16 as a white powder $(820 \mathrm{mg}, 53 \%) .{ }^{1} \mathrm{H} \mathrm{NMR}\left(\mathrm{CD}_{3} \mathrm{CN}\right.$ $200 \mathrm{MHz}) \delta 8.88$ (bs, 2H, BipyH), 8.89 (d, 2H, BipyH, $\left.{ }^{3} \mathrm{~J}=7.1 \mathrm{~Hz}\right), 8.32(\mathrm{~d}, 2 \mathrm{H} \mathrm{BipyH}$ $6.6 \mathrm{~Hz}), 7.93(\mathrm{~d}, 2 \mathrm{H}, \mathrm{BipyH}, 5.9 \mathrm{~Hz}), 7.03\left(\mathrm{t}, 1 \mathrm{H}\right.$, para-ArH, $\left.{ }^{4} \mathrm{~J}=1.7 \mathrm{~Hz}\right), 6.72(\mathrm{t}, 2 \mathrm{H}$, ortho-ArH, $\left.{ }^{4} \mathrm{~J}=1.70 \mathrm{~Hz}\right), 4.56\left(\mathrm{t}, 2 \mathrm{H}, \mathrm{BipyCH}_{2},{ }^{3} \mathrm{~J}=7.3 \mathrm{~Hz}\right), 3.97\left(\mathrm{t}, 2 \mathrm{H}, \mathrm{OCH}_{2},{ }^{3} \mathrm{~J}=\right.$ $6.4 \mathrm{~Hz}), 2.01\left(\mathrm{q}, 2 \mathrm{H}, \mathrm{CH} 2,{ }^{3} \mathrm{~J}=6.6 \mathrm{~Hz}\right), 1.74\left(\mathrm{q}, 2 \mathrm{H}, \mathrm{CH}_{2},{ }^{3} \mathrm{~J}=6.6 \mathrm{~Hz}\right), 1.40(\mathrm{bs}, 8 \mathrm{H}$, $\left.\mathrm{CH}_{2}\right), 1.28$ (s, $\left.18 \mathrm{H}, \mathrm{CCH}_{3}\right) \mathrm{ppm}$

\section{1-(11-(3,5-Di-tert-butylphenoxy)undecyl)-4,4'-bipyridin-1-ium}

hexafluorophosphate (17). Compound $14(85 \mathrm{mg}, 0.19 \mathrm{mmol})$ and 4,4-bipyridine (300 $\mathrm{mg}, 1.9 \mathrm{mmol})$ were dissolved in acetonitrile $(10 \mathrm{~mL})$. The mixture was refluxed overnight under argon. After cooling, the solvent was evaporated and the residue was dissolved in $\mathrm{CHCl}_{3}(5 \mathrm{~mL})$. An aqueous saturated $\mathrm{NH}_{4} \mathrm{PF}_{6}$ solution $(5 \mathrm{~mL})$ was added, and the mixture was stirred vigorously for $2 \mathrm{hrs}$. The organic layer was separated, washed with water and evaporated to dryness. The crude product was purified by column chromatography (Silica $\left.60 \mathrm{H}, 3 \% \mathrm{MeOH} / \mathrm{CHCl}_{3}, v / v\right)$ to give $17(112 \mathrm{mg}, 88 \%)$ as an off-white solid. ${ }^{1} \mathrm{H}$ NMR $\left(\mathrm{CDCl}_{3}, 300 \mathrm{MHz}\right) \delta 8.81\left(\mathrm{~d}, 2 \mathrm{H}, \mathrm{BipyH},{ }^{3} \mathrm{~J}=6.0 \mathrm{~Hz}\right)$, $8.70\left(\mathrm{~d}, 2 \mathrm{H}, \mathrm{BipyH},{ }^{3} \mathrm{~J}=5.1 \mathrm{~Hz}\right), 8.13\left(\mathrm{~d}, 2 \mathrm{H}, \mathrm{BipyH},{ }^{3} \mathrm{~J}=6.9 \mathrm{~Hz}\right), 7.58(\mathrm{~d}, 2 \mathrm{H}, \mathrm{BipyH}$ $\left.{ }^{3} \mathrm{~J}=4.5 \mathrm{~Hz}\right), 6.95\left(\mathrm{t}, 1 \mathrm{H}, \mathrm{ArH},{ }^{4} \mathrm{~J}=1.8 \mathrm{~Hz}\right), 6.70\left(\mathrm{~d}, 2 \mathrm{H}, \mathrm{ArH},{ }^{4} \mathrm{~J}=1.8 \mathrm{~Hz}\right), 4.55(\mathrm{t}, 2 \mathrm{H}$ $\left.\mathrm{CH}_{2} \mathrm{~N},{ }^{3} \mathrm{~J}=7.2 \mathrm{~Hz}\right), 3.91\left(\mathrm{t}, 2 \mathrm{H}, \mathrm{ArOCH}_{2}\right), 1.98\left(\mathrm{~m}, 2 \mathrm{H}, \mathrm{CH}_{2}\right), 1.74\left(\mathrm{~m}, 2 \mathrm{H}, \mathrm{CH}_{2}\right), 1.6$ $1.1\left(\mathrm{~m}, 16 \mathrm{H}, \mathrm{CH}_{2}\right), 1.28\left(\mathrm{~s}, 18 \mathrm{H}, \mathrm{CH}_{3}\right) \mathrm{ppm}$

[2]Rotaxane 18. Porphryin $\mathbf{1}(10 \mathrm{mg}, 7.4 \mu \mathrm{mole})$, pyridinium salt 15 (21 mg, 37 mole) and bromide 12 (104 mg, $293 \mu$ mole) were dissolved in DMF $(1.5 \mathrm{ml})$. The resulting solution was stirred overnight at $90^{\circ} \mathrm{C}$ under an argon atmosphere. After cooling, the solvent was evaporated and the resulting solid was dissolved in $\mathrm{MeCN}$. To this solution a saturated aqueous solution of $\mathrm{NH}_{4} \mathrm{PF}_{6}$ was added. Water and $\mathrm{CHCl}_{3}$ were added and the organic layer was separated and evaporated to dryness. The crude mixture was subjected to column chromatography (silica, $\mathrm{CH}_{2} \mathrm{Cl}_{2}-0.3 \% \mathrm{MeOH} / \mathrm{CH}_{2} \mathrm{Cl}_{2}(v / v)$ $\left.0.5 \% \mathrm{MeOH} / \mathrm{CH}_{2} \mathrm{Cl}_{2}, v / v\right)$ to yield 18 as a purple solid $(9 \mathrm{mg}, 51 \%) .{ }^{1} \mathrm{H} \mathrm{NMR}\left(\mathrm{CDCl}_{3}\right.$ $500 \mathrm{MHz}$ ) $\delta 9.11$ (s, 4H, H12), 8.78 (s, 4H, H13), 8.09 (dd, 4H, H11, ${ }^{3} \mathrm{~J}=7.4 \mathrm{~Hz},{ }^{5} \mathrm{~J}=$ $1.7 \mathrm{~Hz}), 7.80\left(\mathrm{dt}, 4 \mathrm{H}, \mathrm{H10},{ }^{3} \mathrm{~J}=8.0 \mathrm{~Hz},{ }^{5} \mathrm{~J}=1.7 \mathrm{~Hz}\right), 7.44\left(\mathrm{t}, 4 \mathrm{H}, \mathrm{H} 9,{ }^{3} \mathrm{~J}=7.4 \mathrm{~Hz}\right), 7.40$ $\left(\mathrm{d}, 4 \mathrm{H}, \mathrm{H} 8,{ }^{3} \mathrm{~J}=8.5 \mathrm{~Hz}\right), 7.06\left(\mathrm{t}, 2 \mathrm{H}\right.$, para-ArH (thread), $\left.{ }^{5} \mathrm{~J}=1.5 \mathrm{~Hz}\right), 7.05-6.96(\mathrm{~m}, 6 \mathrm{H}$ $\mathrm{H} 1,2), 6.92-6.88(\mathrm{~m}, 4 \mathrm{H}, \mathrm{H} 3), 6.83$ (d, 4H, ortho-ArH (thread), $\left.{ }^{5} \mathrm{~J}=1.6 \mathrm{~Hz}\right), 6.15$ (bd, $4 \mathrm{H}, \mathrm{BipyH},{ }^{3} \mathrm{~J}=5.2 \mathrm{~Hz}$ ), 6.07 (s, 4H, H5), 4.96 (bs, 4H, BipyH), 4.35 (m, 4H, H7), 4.23 $\left(\mathrm{d}, 4 \mathrm{H}, \mathrm{H} 4,{ }^{2} \mathrm{~J}=15.9 \mathrm{~Hz}\right), 4.02(\mathrm{~m}, 4 \mathrm{H}, \mathrm{H} 7), 3.96\left(\mathrm{t}, 4 \mathrm{H}, \mathrm{OCH}_{2}(\right.$ thread $\left.),{ }^{3} \mathrm{~J}=6.0 \mathrm{~Hz}\right)$, 3.69 (d, $\left.4 \mathrm{H}, \mathrm{H} 4,{ }^{2} \mathrm{~J}=15.8 \mathrm{~Hz}\right), 3.51(\mathrm{~m}, 4 \mathrm{H}, \mathrm{H6}), 3.32\left(\mathrm{bt}, 4 \mathrm{H}, \mathrm{BipyCH}_{2}\right), 2.80(\mathrm{~m}, 4 \mathrm{H}$ $\mathrm{H} 6), 1.74$ (q, $4 \mathrm{H}, \mathrm{CH}_{2}$ (thread), $\left.{ }^{3} \mathrm{~J}=7.2 \mathrm{~Hz}\right), 1.36\left(\mathrm{~s}, 36 \mathrm{H}, \mathrm{CCH}_{3}\right), 1.31\left(\mathrm{q}, 4 \mathrm{H}, \mathrm{CH}_{2}\right.$ (thread), ${ }^{3} \mathrm{~J}=6.1 \mathrm{~Hz}$ ), 0.99 (bs, 4H, $\mathrm{CH}_{2}$ (thread)), 2.82 (s, 2H, H14) ppm. MALDITOF: $m / z 2052(\mathrm{M}-2 \mathrm{PF} 6)^{+}$

[2]Rotaxane 19. Porphryin 1 ( $10 \mathrm{mg}, 7.4$ umole), pyridinium salt 16 (23 mg, 37 umole) and bromide $13(118 \mathrm{mg}, 296 \mu$ mole $)$ were dissolved in DMF $(1.5 \mathrm{ml})$. The resulting solution was stirred overnight at $90^{\circ} \mathrm{C}$ under an argon atmosphere. After cooling, the solvent was evaporated and the resulting solid was dissolved in $\mathrm{MeCN}$. To this solution a saturated aqueous solution of $\mathrm{NH}_{4} \mathrm{PF}_{6}$ was added. Water and $\mathrm{CHCl}_{3}$ were added and the organic layer was separated and evaporated to dryness. The crude mixture was subjected to column chromatography (silica, $\mathrm{CH}_{2} \mathrm{Cl}_{2}-0.3 \% \mathrm{MeOH} / \mathrm{CH}_{2} \mathrm{Cl}_{2}(v / v)$ $\left.0.5 \% \mathrm{MeOH} / \mathrm{CH}_{2} \mathrm{Cl}_{2}(v / v)\right)$ to yield 19 as a purple solid $(11 \mathrm{mg}, 61 \%)$. ${ }^{1} \mathrm{H}$ NMR $\left(\mathrm{CDCl}_{3}, 300 \mathrm{MHz}\right) \delta 9.08(\mathrm{~s}, 4 \mathrm{H}, \mathrm{H} 12), 8.77(\mathrm{~s}, 4 \mathrm{H}, \mathrm{H} 13), 8.10\left(\mathrm{dd}, 4 \mathrm{H}, \mathrm{H} 11,{ }^{3} \mathrm{~J}=7.4\right.$ $\left.\mathrm{Hz},{ }^{5} \mathrm{~J}=1.7 \mathrm{~Hz}\right), 7.82\left(\mathrm{dt}, 4 \mathrm{H}, \mathrm{H} 10,{ }^{3} \mathrm{~J}=8.0 \mathrm{~Hz},{ }^{5} \mathrm{~J}=1.7 \mathrm{~Hz}\right), 7.44\left(\mathrm{t}, 4 \mathrm{H}, \mathrm{H} 9,{ }^{3} \mathrm{~J}=7.4\right.$ $\mathrm{Hz}), 7.41\left(\mathrm{~d}, 4 \mathrm{H}, \mathrm{H} 8,{ }^{3} \mathrm{~J}=8.5 \mathrm{~Hz}\right), 7.05\left(\mathrm{t}, 2 \mathrm{H}\right.$, para-ArH (thread), $\left.{ }^{5} \mathrm{~J}=1.5 \mathrm{~Hz}\right), 7.04$ $6.97(\mathrm{~m}, 6 \mathrm{H}, \mathrm{H1}, 2), 6.94-6.89(\mathrm{~m}, 4 \mathrm{H}, \mathrm{H} 3), 6.85$ (d, 4H, ortho-ArH (thread), ${ }^{5} \mathrm{~J}=1.6$ $\mathrm{Hz}), 6.13\left(\mathrm{~d}, 4 \mathrm{H}, \mathrm{BipyH},{ }^{3} \mathrm{~J}=6.1 \mathrm{~Hz}\right), 6.07(\mathrm{~s}, 4 \mathrm{H}, \mathrm{H} 5), 4.90\left(\mathrm{~d}, 4 \mathrm{H}, \mathrm{BipyH},{ }^{3} \mathrm{~J}=6\right.$. $\mathrm{Hz}), 4.40-4.35$ (m, 4H, H7), 4.28 (d, 4H, H4, $\left.{ }^{2} \mathrm{~J}=15.9 \mathrm{~Hz}\right), 4.05-3.95(\mathrm{~m}, 4 \mathrm{H}, \mathrm{H} 7), 4.05$ (t, $4 \mathrm{H}, \mathrm{OCH}_{2}$ (thread), $\left.{ }^{3} \mathrm{~J}=6.0 \mathrm{~Hz}\right), 3.73\left(\mathrm{~d}, 4 \mathrm{H}, \mathrm{H} 4,{ }^{2} \mathrm{~J}=15.8 \mathrm{~Hz}\right), 3.56-3.46(\mathrm{~m}, 4 \mathrm{H}$ H6), 3.32 (bt, $4 \mathrm{H}, \mathrm{BipyCH}_{2}$ ), 2.82-2.73 (m, 4H, H6), 1.85 (q, 4H, $\mathrm{CH}_{2}$ (thread), ${ }^{3} \mathrm{~J}=7.2$ $\mathrm{Hz}$ ), $1.60-1.50$ (m, 4H, $\mathrm{CH}_{2}$ (thread)), 1.42-1.20 (m, 8H, $\mathrm{CH}_{2}$ (thread)), 1.35 (s, $36 \mathrm{H}$ $\mathrm{CCH}_{3}$ ), 1.10 (bs, $4 \mathrm{H}, \mathrm{CH}_{2}$ (thread)), 0.94 (bs, $4 \mathrm{H}, \mathrm{CH}_{2}$ (thread)), -2.82 (s, 2H, H14) ppm. MALDI-TOF: $m / z 2136\left(\mathrm{M}-2 \mathrm{PF}_{6}\right)^{+}$

[2]Rotaxane 20. Compounds $14(22 \mathrm{mg}, 50 \mathrm{mmol}), \mathbf{1 7}(22 \mathrm{mg}, 33 \mathrm{mmol})$ and $\mathbf{1}(8.5 \mathrm{mg}$ $6.3 \mathrm{mmol})$ were suspended in argon-flushed DMF $(3 \mathrm{~mL})$. The mixture was heated under argon at $120^{\circ} \mathrm{C}$ for 5 days. After cooling, the product was dissolved in $\mathrm{CHCl}_{3}$ (5 $\mathrm{mL})$. A saturated aqueous $\mathrm{NH}_{4} \mathrm{PF}_{6}$ solution $(5 \mathrm{~mL})$ was added and the mixture was stirred vigorously for $2 \mathrm{hrs}$. The organic layer was separated, washed with water and evaporated to dryness. The crude product was purified by column chromatography (first column: Silica $60 \mathrm{H}, 2 \% \mathrm{MeOH}$ in $\mathrm{CHCl}_{3}, v / v$; second column: size exclusion, toluene to give $20(6 \mathrm{mg}, 38 \%)$ as a purple solid. ${ }^{1} \mathrm{H} \mathrm{NMR}\left(\mathrm{CDCl}_{3}, 300 \mathrm{MHz}\right) \delta 9.07(\mathrm{~s}, 4 \mathrm{H}$, $\mathrm{H} 12$ ), 8.79 (s, 4H, H13), 8.11 (dd, $4 \mathrm{H}, \mathrm{H} 11,{ }^{3} \mathrm{~J}=7.4 \mathrm{~Hz},{ }^{5} \mathrm{~J}=1.7 \mathrm{~Hz}$ ), 7.83 (dt, $4 \mathrm{H}, \mathrm{H} 10$, $\left.{ }^{3} \mathrm{~J}=8.0 \mathrm{~Hz},{ }^{5} \mathrm{~J}=1.7 \mathrm{~Hz}\right), 7.46\left(\mathrm{t}, 4 \mathrm{H}, \mathrm{H} 9,{ }^{3} \mathrm{~J}=7.4 \mathrm{~Hz}\right), 7.42\left(\mathrm{~d}, 4 \mathrm{H}, \mathrm{H} 8,{ }^{3} \mathrm{~J}=8.5 \mathrm{~Hz}\right)$ $7.03\left(\mathrm{t}, 2 \mathrm{H}\right.$, para-ArH (thread), $\left.{ }^{5} \mathrm{~J}=1.5 \mathrm{~Hz}\right), 7.05-6.99(\mathrm{~m}, 6 \mathrm{H}, \mathrm{H} 1,2), 6.95-6.88(\mathrm{~m}, 4 \mathrm{H}$ $\mathrm{H} 3), 6.81\left(\mathrm{~d}, 4 \mathrm{H}\right.$, ortho-ArH (thread), $\left.{ }^{5} \mathrm{~J}=1.6 \mathrm{~Hz}\right), 6.14\left(\mathrm{~d}, 4 \mathrm{H}, \mathrm{BipyH},{ }^{3} \mathrm{~J}=6.1 \mathrm{~Hz}\right)$,
6.08 (s, 4H, H5), 4.89 (bs, 4H, BipyH), 4.39-4.30 (m, 4H, H7), 4.28 (d, 4H, H4, ${ }^{2} \mathrm{~J}=$ $15.9 \mathrm{~Hz}), 4.10-4.00(\mathrm{~m}, 4 \mathrm{H}, \mathrm{H} 7), 4.03\left(\mathrm{t}, 4 \mathrm{H}, \mathrm{OCH}_{2}\right.$ (thread), $\left.{ }^{3} \mathrm{~J}=6.0 \mathrm{~Hz}\right), 3.74(\mathrm{~d}, 4 \mathrm{H}$ $\left.\mathrm{H} 4,{ }^{2} \mathrm{~J}=15.8 \mathrm{~Hz}\right), 3.58-3.49(\mathrm{~m}, 4 \mathrm{H}, \mathrm{H6}), 3.32\left(\mathrm{bs}, 4 \mathrm{H}, \mathrm{BipyCH}_{2}\right), 2.84-2.75(\mathrm{~m}, 4 \mathrm{H}$, H6), 1.87-0.8 (m, 36H, $\mathrm{CH}_{2}$ (thread)) 1.33 (s, $\left.36 \mathrm{H}, \mathrm{CCH}_{3}\right),-2.81$ (s, 2H, H14) ppm. MALDI-TOF: $m / z 2220\left(\mathrm{M}-2 \mathrm{PF}_{6}\right)^{+}$.

\section{Acknowledgements}

This research was supported by the European Research Council in the form of an ERC Starting grant for J.A.A.W.E (NANOCAT-259064) and an ERC Advanced grant for R.J.M.N. (ALPROS-290886). The Dutch National Research School for Combination Catalysis (NRSC-C) is acknowledged for financial support to R.G.E.C and R.J.M.N Further financial support was obtained from the Council for the Chemical Sciences of The Netherlands Organization for Scientific Research (CW-NWO) (Vidi grant for J.A.A.W.E and Vici grant for A.E.R)

[1] a) D. B. Amabilino, J. F. Stoddart, Chem. Rev. 1995, 95, 2725. b) A. R. Pease, J. O. Jeppesen, J. F. Stoddart, Y. Luo, C. P. Collier, J. R. Heath, Acc. Chem. Res. 2001, 34, 443. c) K. Kim, Chem. Soc. Rev. 2002, 31, 96. d) A. H. Flood, R. J. A. Ramirez, W. Q. Deng, R. P. Muller, W. A. Goddard, J. F. Stoddart, Aust.. J. Chem, 2004, 57, 301. e) S. J. Cantrill, K. S. Chichak, A. J. Peters, J. F. Stoddart, Acc. Chem. Res. 2005, 38, 1. f) J. F. Stoddart, Chem. Soc. Rev. 2009, 38, 1802. g) R. S. Forgan, J.-P. Sauvage, J. F. Stoddart, Chem. Rev. 2011, 111, 5434.

[2] a) C. P. Collier, G. Mattersteig, E. W. Wong, Y. Luo, K. Beverly, J. Sampaio,F. M. Raymo, J. F. Stoddart, J. R. Heath, Science 2000, 289, 1172. b) Y. Luo, C. P. Collier, J. O. Jeppesen, K. A. Nielsen, E. Delonno, G. Ho, J. Perkins, H. R.Tseng, T. Yamamoto, J. F. Stoddart, J. R. Heath, ChemPhysChem 2002, 3, 519 .

[3] a) T. J. Huang, B. Brough, C. M. Ho, Y. Liu, A. H. Flood, P. A. Bonvallet, H. R. Tseng, J. F. Stoddart, M. Baller, S. Magonov, Appl. Phys. Lett. 2004, 85, 5391. b) Y. Liu, A. H. Flood, P. A. Bonvallett, S. A. Vignon, B. H. Northrop, H. R. Tseng, J. O. Jeppesen, T. J. Huang, B. Brough, M. Baller, S. Magonov, S. D. Solares, W. A. Goddard, C. M. Ho, J. F. Stoddart, J. Am. Chem. Soc. 2005, 127, 9745 .

[4] Not only interlocked molecules are excellent candidates for the bottom-up approach in nano-technology, see for example: a) N. Koumura, R. W. J. Zijlstra, R. A. van Delden, N. Harada, B. L. Feringa, Nature 1999, 401, 152. b) V. Balzani, A. Credi, F. M. Raymo, J. F. Stoddart, Angew. Chem. Int. Ed. 2000, 39 , 3349. c) K. Kinbara, T. Aida, Chem. Rev. 2005, 105, 1377. d) A. Kocer, M Walko, W. Meijberg, B. L. Feringa, Science 2005, 309, 755. W. R. Browne, B L. Feringa, Nat. Nanotech. 2006, 2, 25. e) K. Miwa, Y. Furusho, E. Yashima, Nat. Chem. 2010, 2, 444

[5] A. M. Turing, A.M. Proc. London Math. Soc. 1937, 42, 230.

[6] a) P. Thordarson, E. J. A. Bijsterveld, A. E. Rowan, R. J. M. Nolte, Nature 2003 424, 915. b) C. Monnereau, P. Hidalgo Ramos, A. B. C. Deutman, J. A. A. W. Elemans, R. J. M. Nolte, A. E. Rowan, J. Am. Chem. Soc. 2010, 132, 1529.

[7] P. Thordarson, R. G. E. Coumans, J. A. A. W. Elemans, P. J. Thomassen, J. Visser, A.E. Rowan, R. J. M. Nolte, Angew. Chem. Int. Ed. 2004, 43, 4755.

[8] a) R. G. E. Coumans, J. A. A. W. Elemans, R. J. M. Nolte, A. E. Rowan, Proc Natl. Acad. Sci. USA, 2006, 103, 19647. b) P. Hidalgo Ramos, R. G. E. Coumans, A. B. C. Deutman, R. de Gelder, J. M. M. Smits, J. A. A. W. Elemans, R. J. M. Nolte, A. E. Rowan, J. Am. Chem. Soc., 2007, 129, 5699. c) A. B. C. Deutman, C. Monnereau, J. A. A. W. Elemans, G. Ercolani, R. J. M. Nolte, A. E. Rowan, Science, 2008, 322, 1668.

[9] R. G. E. Coumans, J. A. A. W. Elemans, P. Thordarson, R. J. M. Nolte, A. E. Rowan, Angew. Chem. Int. Ed. 2003, 42, 650 .

[10] J. A. A. W. Elemans, M. B. Claase, P. P. M. Aarts, A. E. Rowan, A. P. H. J. Schenning, R. J. M Nolte, J. Org. Chem., 1999, 64, 7009.

[11] a) B. Mohr, M. Weck, J.-P. Sauvage, R. H. Grubbs, Angew. Chem. Int. Ed 1997 109, 1365. b) T. J. Kidd, D. A. Leigh, A. J. Wilson, J. Am. Chem. Soc. 1999, 121, 1599. c) P. Mobian, J. M. Kern, J.-P. Sauvage, J. Am. Chem. Soc. 2003 125 , 2016. d) A. F. M. Kilbinger, S. J. Cantrill, A. W. Waltman, M. W. Day, R. H. Grubbs, Angew. Chem. Int. Ed. 2003, 42, 3281. e) G. Kaiser, S. Jarrosson, S. Otto, Y. F. Ng, A. D. Bond, J. K. M. Sanders, Angew. Chem. Int. Ed. 2004, 43 , 1959. f) J. D. Badjic, S. J. Cantrill, R. H. Grubbs, E. N. Guidry, R. Orenes, J. F. Stoddart, Angew. Chem. Int. Ed. 2004, 43, 3273. g) P. G. Clark, E. N. Guidry, W. Y. Chan, W. E. Steinmetz, R. H. Grubbs, J. Am. Chem. Soc. 2010, 132, 3405.

[12] For some examples of other porphyrin containing catenanes, see: a) M. J. Gunter, D. C. R. Hockless, M. R. Johnston, B. W. Skelton, A. H. White, J. Am. Chem Soc. 1994, 116, 4810. b) M. Linke, N. Fujita, J. C. Chambron, V. Heitz, J.-P. Sauvage, New J. Chem. 2001, 25, 790. c) M. J. Gunter, S. M. Farquhar, Org. Biomol. Chem. 2003, 1, 3450. d) M. Beyler, V. Heitz, J.-P. Sauvage, Chem. Commun. 2008, 5396. e) M. J. Langton, J. D. Matichak, A. L. Thompson, H. L. Anderson, Chem. Sci. 2011, 2, 1897.

[13] A similar statistical approach to the synthesis of simple molecular necklaces using Glaser-Hay coupling has been published: F. Bitsch, C. O. DietrichBuchecker, J. P. Khemiss, J.-P.Sauvage, A. Van Dorsselaer, J. Am. Chem. Soc. 1991, 113, 4023 . 
[14] For some other examples of molecular necklaces, see: a) D. B. Amabilino, P. R Ashton, J. F. Stoddart, A. J. P. White, D. J. Williams, Chem. Eur. J. 1998, 4 460. b) D. Whang, K. M. Park, J. Heo, P. Ashton, K. Kim, J. Am. Chem. Soc 1998, 120, 4899. c) Y. H. Ko, K. Kim, J. K. Kang, H. Vhun, J. W. Lee, S. Sakamoto, K. Yamaguchi, J. C. Fettinger, K. Kim, J. Am. Chem. Soc. 2004, 126, 1932.

[15] M. J. Gunter, M. R. Johnston, J. Chem. Soc., Chem. Commun. 1994, 829.

[16] For some examples of induced motion in interlocked molecules, see: a) A. S. Lane, D. A. Leigh, A. Murphy, J. Am. Chem. Soc. 1997, 119, 11092. b) P. R. Ashton, R. Ballardini, V. Balzani, I. Baxter, A. Credi, M. C. T. Fyfe, M. T. Gandolfi, M. Gómez-López, M.-V. Martínez-Díaz, A. Piersanti, N. Spencer, J. F. Stoddart, M. Venturi, A. J. P. White, D. J. Williams, J. Am. Chem. Soc. 1998 120, 11932. c) A. M. Brouwer, C. Frochot, F. G. Gatti, D. A. Leigh, L. Mottier, F. Paolucci, S. Roffia, G. W. H. Wurpel, Science 2001, 291, 2124.. d) A. Altieri, G. Bottari, F. Dehez, D. A. Leigh, J. K. Y. Wong, F. Zerbetto, Angew. Chem. Int. Ed. 2003, 42, 2296. e) D. A. Leigh, J. K. Y. Wong, F. Dehez, F. Zerbetto, Nature 2003, 424, 174. f) J. D. Badjic, V. Balzani, A. Credi, S. Silvi, J.-F. Stoddart, Science 2004, 303, 1845. g) V. Serreli, C.-F. Lee, E. R. Kay, D. A Leigh, Nature, 2007, 445, 523 .

[17] I. O. Sutherland, Annu. Rep. NMR Spectrosc. 1971, 4, 71.

[18] For some other examples of switchable interlocked molecular machines with fluorescent signals, see: a) Q.-C. Wang, D.-H. Qu, J. Ren, K. Chen, H. Tian, H Angew. Chem., Int. Ed. 2004, 43, 2661. b) E. M. Perez, D. T. F. Dryden, D. A Leigh, G. Teobaldi, F. Zerbetto, J. Am. Chem. Soc. 2004, 126, 12210. c) D. A Leigh, M. A. F. Morales, E. M. Perez, J. K. Y. Wong, C. G. Saiz, A. M. Z. Slawin, A. J. Carmichael, D. M. Haddleton, A. M. Brouwer, W. J. Buma, G. W. H. Wurpel, S. Leon, F. Zerbetto, Angew. Chem. Int. Ed. 2005, 44, 3062. 